Historic, Archive Document

Do not assume content reflects current scientific knowledge, policies, or practices. 

ESTABLISHED 1867.

INCORPORATED 1903.

CAPITAL $\$ 50,000.00$ FULL PAID.

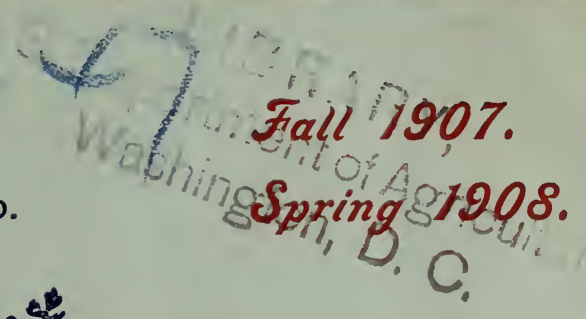

\section{Price List.}

\section{(3) (3) (3) (2)}

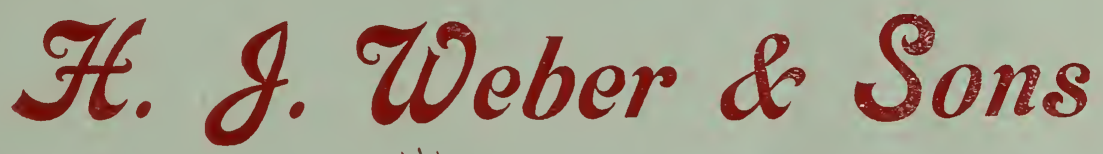

111

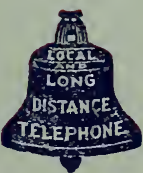

gursery Co.,

Mursory, St. Louis Co., Mo.

Nurseries and Office, located on Gravois Road.

One and one quarter miles west of St Louis City Limits. Nine miles southwest of St. Louis Court House, and one and one half miles west of terminus of the "Cherokee Street Car Line," or one half mile east of Gravois Station on the St. Louis \& San Francisco R. R. (St. Louis, Cape Girardeau and Memphis Division), two trains each way daily. 


\section{INTRODUCTORY.}

WITH great pleasure we again present for your perusal our annual Price List for the Fall of 1907 and Spring 1908, covering the various Trees, Vines, Shrubs, Roses and Plants described in our Descriptive Catalogue under their respective headings.

We wish to extend to our many Patrons our sincere thanks for their liberal patronage and hope that we have merited a continuance of your valued orders the coming year.

To those receiving this list with whom we have not had the pleasure of dealing, we give the following information:

Our Nurseries cover over 200 Acres of the best Nursery land in Missouri, being of the "Loess formation" which is specially adapted to the growing of strong, healthy trees and plants, with plenty of fibrous roots.

The packing facilities are the best of any Nursery near St. Louis, and all packing and filling of orders is personally superintended by members of the firm with the assistance of competent help, in the best possible manner; no distance too great for our mode of packing.

We usually begin packing in the fall, about October $15^{\text {th }}$, and extend to November I 5 th, or until freezing up, and in spring from March ist to May ist.

You are cordially invited to visit our Nurseries, we are always pleased to show visitors through our grounds.

During the last six or seven years we have increased our Ornamental plantings and now have to offer a very complete line for Home, Club and Institution grounds, Parks, Cemeteries, etc.

We solicit your correspondence and inquiries, and are always glad to assist you in making selections.

Awaiting your favors, we are

\section{H. J. Weber \& Sons Nursery Co.}

\section{Agricultural College of Missouri, Experiment Station.}

DEPARTMENT OF ENTOMOLOGY. CERTIFICATE OF INSPECTION OF NURSERY STOCK.

\section{COLUMBIA, MO., August 5TH, 1907.}

TO WHOM IT MAY CONCERN :-This is to certify that on the 2 nd day of August, the Nursery Stock of the H. J. Weber \& Sons Nursery Co., H. J. Weber \& Sons, proprietors, grown in their nurseries at and in the vicinity of Nursery, St. Louis County, Missouri, was examined and no indication found of the presence of San Jose Scale, Peach Yellows, Rosette or other dangerous insects or plant diseases liable to be transferred on nursery stock from the nursery to the orchard.

This certificate is good for one year from date of inspection. Leonard Hoseman, Deputy Inspector. J. F. Stedman, Entomologist . 


\section{PLEASE READ CAREFULLY.}

\section{TERMS, CONDITIONS AND GENERAL REMARKS.}

Terms:-Invariably cash, except when otherwiseagreed upon.

Remit by P. 0 . or Express money order on St. Louis, Mo., Registered Letter on Nursery, Mo., or by Draft. Please do not send private checks unless drawn on some St. Louis Bank. Address all letters to "H. J. Weber \& Sons Nursery Co.," Nursery, Mo.-C. O. D. orders must be accompanied with one-half the amount in cash.

Quotations in this list are made subject to previous sales and without liability should injury befall stock from frost, fire, hail or other causes beyond our control.

Guarantee.-We exercise the greatest care to have every tree and plant true to name, and are ready, on proper proof, to replace anything sent out by us, that may prove untrue to label, free of charge, or refund the money paid for same. It is understood between purchaser and ourselves, that we are not to be held liable for any.greater sum than that paid us for said trees and plants that prove untrue.

Freo Packing. - We pack free all orders sold at Catalogue prices in the best possible manner, in bales or boxes, with moss or excelsior.

No Cartage-to Freight Depots, Express Offices or Wharfs in St. Louis.

City of St. Louis and Suburban Deliveries.-Parties desiring to receive their order on a certain day or immediately on receipt of same, will please have it shipped by some Local Express Company. Express charges are to be paid by purchaser.

City Delivery Wagons, will make trips to the various sections of St. Louis; orders to go this way must be left entirely with us as to time of delivery. We combine a number of orders for one section in making these deliveries. We cannot make special trips unless order is large enough to make a load.

Now Railroad Facilities.-We have the "St. Louis, Cape Girardeau and Memphis R. R." branch of the "Frisco System" within one-half mile of the Office. Our station is "Gravois, Mo." "Wells Fargo Express" Car Load shipments loaded here. This with the St. Louis facilities enables us to make prompt shipments on direct lines. 
Early Orders. - Customers should send in orders as early as possible; do not wait until the last minute. Wishing to serve our patrons to the best of their interest we kindly ask for early orders.

Directions.-Observe carefully that your name, P. O., County and State are plainly written on your order; also state whether to be sent by Freight or Express, and by what route. If no directions are given, we will use our best judgment in the matter.

Errors.-Any errors that may occur in filling orders must be reported within five days after receipt of goods. We will immediately correct same. Complaints entered after the above stated time cannot be entertained.

Losses.-All stock will be sent out in good condition; we do not guarantee stock to live under all conditions, nor do we make up any loss whatever due to climatic effects, or after culture on the part of the purchaser. On receipt of stock open package at once and ascertain condition of same, check up varieties and compare with your order and report to us at once. (If package has been frosted or become dry en-route, treat as per instructions given in catalogue, under Directions for Transplanting and care of Trees, Shrubs, etc.)

SUBSTITUTION.-It is customary, should the supply of a variety become exhausted (as will occasionally occur in all establishments), to substitute in its place a similar sort, if there is such. Should it be desirable for us not to do this, please state "No Substitution" on your order.

Selections.-Persons unacquainted with the different varieties can leave the selection to us, in which case we will select as if planting for ourselves.

Transportation.-Every care is taken to secure safe and prompt transportation. The forwarders alone must be held responsible for loss or delay in transit.

Inspection.-Our nurseries are annually inspected by the State Entomologist and have been found free of San Jose Scale and other dangerous insects and diseases. A copy of certificate of inspection will be attached to every package that leaves our establishment.

Fumigation.-Having built our own "Fumigatorium" we will fumigate with "Hydrocyanic Acid Gas," all stock sent to States where same is required by law. Should any of our customers request us to "Fumigate" their stock we will be pleased to do so, free of extra charge.

Notice.-The prices in this list abrogate previous quotations, and are made on stock to be strictly first class of the grades named. Please do not compare our prices with firms quoting on mailing size trees and plants only.

\section{H. J. WEBER \& SONS NURSERY CO.,}

NURSERY, ST. LOUIS, CO., MO. 


\section{FRUIT DEPARTMENT.}

APPLES.

Our Apples are all "crown grafted" on branched roots, none better.

Éacb. Per 10. Per 100.

First class 5 to 6 feet........................ \$0.25 \$2.00 \$15.00

Medium class 4 to 5 feet........................ .20 $1.50 \quad 12.00$

Summer or Early. Early Winter. Gano.

Yellow Transparent. Talman Sweet.

Carolina Red June. Wolf River.

Early Harvest.

Duchess of Oldenburg.

Red Astrachan.

Sweet June.

Chenango Strawberry.

Fameuse.

\section{A utumn.}

Wealthy.

Maiden Blush.

Rambo.
Jonathan.

Grimes Golden.

Northern Spy.

\section{Winter.}

Baldwin.

Huntsman.

Northwestern Greening.

Missouri Pippin.

Rume Beauty.

Yellow Belleflower.

Ben. Davis.

York Imperial.
Gilpin, or Little Red Romanite.

Jennett (Rawles.)

Wine Sap.

Salome.

Ingram.

Mammoth Black Twig.

Arkansas Black.

Crab.

Hyslop.

Transcendent.

Large Red Siberian.

Martha.

General Grant.

\section{PEACHES.}

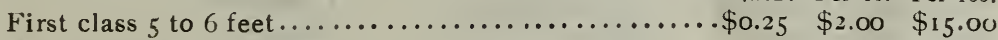

Nedium class 4 to 5 feet........................ .20 $1.50 \quad 12.00$

Second class 3 to 4 feet.........................$_{15} 1.20 \quad 10.00$

Varieties marked with $\left(^{*}\right) 5$ cents per tree higher on all grades.

First Ripening. Family Favorite.

Sneed.

* May Lee Cling.

$\Lambda$ lexander.

Second Ripening.

* Pearson

*Rogers.

Triumph.

Greensboro.

Carmen.

Third Ripening.

Belle of Georgia.

Mt. Rose.

O. M. Free.
Mamie Ross.

Yellow St. John.

Champion.

Crawford Ey.

Fourth Ripening.

Chinese Cling.

Elberta.

*Arp Beauty.

O. M. Cling.

Carpenter Cling.

Newington Cling.
Captain Ede.

Fitzgerald.

Fifth Ripening.

Lemon Cling.

Emma.

Crawford Late.

Stump the World.

*Oriole Cling.

Picquet Late.

Sixth Ripening.

Salway.

White Heath Cling.

Krummels Late.

*Dulce. 


\section{PEARS.}

Standard, first class 5 to 6 feet.

Each. Per 10. Per 100.

" medium. class 4 to 5 feet................40 $3.00 \quad 25.00$

Dwarf, first class 4 to 5 feet.............................. $3.00 \quad 25.00$

"6 medium class 3 to 4 feet........................... $2.50 \quad 20.00$

The letters "D" and "S" appended to the names of varieties, indicate favorable growth, either as Dwarfs or Standards, or both.

Summer.

Autumn.

Doyenne De Ette (S-D.) Howell (S-D.)

Louise Bonne De Jeresy.

(D.)

Bartlett-Seckel or Columbia (S.)

Flemish Beauty (S.)

Seckel (S.)

Sheldon (S.)
Garber (S.)

Worden-Seckel (S.)

Kieffer Hybrid (S.)

Beurre de Anjou (S-D.)

Duchesse De Angouleme) (D.)

Beurre De Clairgeau (S. winter.

Lawrence (S.)

\section{CHERRIES.}

First class 5 to 6 feet Each. Per ro. Per roo.

Those marked with $(*)$ are sweet sorts.

* Abesse (Sweet Duke.) *Black Heart.

Royal Duke.

Suda IIardy.

Ostheimer (Weichsel.)

Early Richmond.

*Napoleon.

May Duke.
*Black Tartarian.

Dye House.

English Morello.

*Elton.

*Reine Ilortense.
*Yellow Spanish.

Montmorency Ordinaire. Montmorency Large.

Late Duke.

Wragg.

*Gov. Wood.

\section{PLUMS.}

European or Foreign sorts, budded on Plum Stock.

First class 5 to 6 feet....................... \$0.50 $\$ 4.00 \$ 30.00$

" " 4 to 5 feet.......................... .40 $3.00 \quad 25.00$

German Prune.

Shropshire Damson.

Damson (Common

Blue.)
Imperial Gage.

Tatge.

Lombard.

Moore's Arctic.
Coe's Golden Drop.

Smith's Orleans.

Bradshaw.

Geuii.

Chickasaw, budded on Plum Stock.

First class 5 to 6 feet........................ \$0.50 \$4.00 $\$ 30.00$

Medium class t to 5 feet.......................... $40 \quad 3.00 \quad 25.00$

Charles Downing.

Milton.

Pottawattamie.

Wild Goose.

Newman 
Each. Per 10. Per 100.

Japan or Oriental sorts, budded on Plum Stock.

First class 5 to 6 feet........................ \$0.50 \$4.00 $\$ 30.00$

Medium class 4 to 5 feet........................ . $30 \quad 3.00 \quad 25.00$

Wickson. Red June (Red Nagate). Botan.

Willard. Burbank.

\section{QUINCES.}

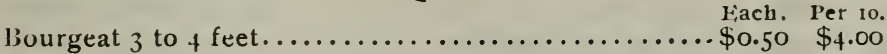

Meech, Orange and Champion 3 to 4 feet........... $.40 \quad 3.50$

\section{APRICOTS.}

First class 4 to 5 feet.

Each. Per io, Per 100.

Medium class 3 to 4 feet.

Early Golden.

Moorpark.
J. L. Budd (Russian). Alexis (Russian).

Alexander (Russian). Superb.

Catherine (Russian).

\section{MULBERRIES.}

Downing and New American 5 to 6 feet $\ldots \ldots \ldots \ldots$ Per 10. Downing and New American 5 to 6 feet $\ldots \ldots \ldots \ldots \ldots . \$ 0.50 \quad \$ 4.00$ Russian 5 to 6 feet............................. .30 2.50

White (Morus $\Lambda \mathrm{lba}$ ) 4 to 6 feet................... 40 . 3.00

\section{PERSIMMONS.}

5 to 6 feet

Fiach. Per 10. $\$ 0.50 \$ 4.00$

\section{NUTS.}

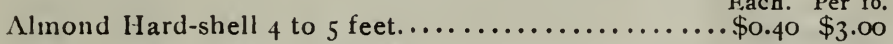

Chestnut Am. Sweet 5 to 6 feet

$400 \$ 3000$

" " " " 4 to 5 feet..................... .40 $3.00 \quad 20.00$

" " " " 3 to 4 feet..................... $30 \quad 2.00$

" Japan or Giant 2 to 3 feet................... .75 6.00

" " " " " $11 \frac{1}{2}$ to 2 feet. $\ldots \ldots \ldots \ldots \ldots \ldots . .50 \quad 4.00$

" " " " $" S$ to $12 \mathrm{in.} \mathrm{seedlings...........} \mathrm{.20} 1.50$

"Paragon 4 to 5 feet (grafted) ............... 1.00

Filberts, English variety Avellana 3 to + feet............40 3.00

Walnut (Japan) Seiboldi $S$ to 10 feet specimens ........ 1.50 I0.00

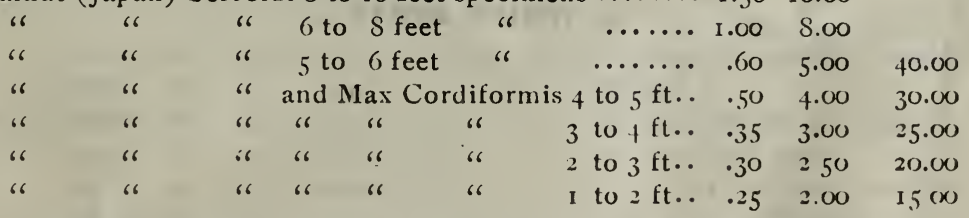


Each. Per 10, Per 100.

Walnut American Black + to 5 feet.............. \$0.40 $\$ 3.00 \$ 2500$

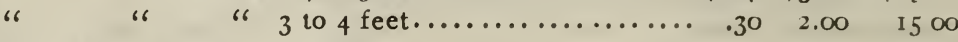

Pecan Seedlings 18 to 24 inches................ 40.00

\section{GOOSEBERRIES.}

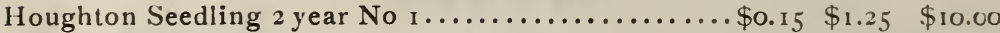

Downing, Pearl and Red Jacket 2 year No. I ........ . .20 $1.50 \quad 12.00$

Keepsake and Columbus 2 year No $1 \ldots \ldots \ldots \ldots \ldots \ldots \ldots .25 \quad 2.00$

\section{CURRANTS.}

Fay's Prolific 2 year No. I.................... \$o. I5 \$1.00 \$6.00

White Dutch and Wilder 2 year No. I............... $15 \quad 1.00 \quad 6.00$

Victoria, Red Dutch, Cherry and La Versailles 2 yr No. I .I 5 I.co 500

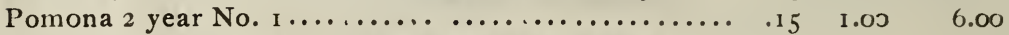

Black Champion 2 year No. I .................... I5 $1.00 \quad 6.00$

London Market 2 year No. I.................... I5 $1.00 \quad 6.00$

\section{GRAPES.}

Write for prices on large quantities.

\section{BLUE OR BLACK SORTS.}

Each. Per 10. Per 100. Per 1000.

Campbell's Early 2 year No. I ............\$0.20 \$I.50 \$12.00

"6 I year No. I.............. . I5 1.2010 .00

Concord 2 year No. I ....................... . I5 $1.00 \quad 5.00 \$$ \$ $\$$.0.00

" 6 I year No. I... ................. . . . .70 $4.00 \quad 30.00$

Ives Seedling 2 year No. I................ . I5 I.00 500

6 6 6 I year No. I................. .10 .70 4.00

IVorden 2 year No. I........................ 1.5 1.00 6.00 50.00

" 1 year No. I....................... . . .80 $5.00 \quad 40.00$

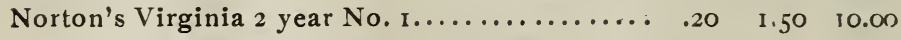

"6 " I year.No. I.............. I5 $1.20 \quad 9.00$

Moore's Early 2 year No. I................. . 5 1.00 $6.50 \quad 5500$

"6 6 1 year No. 1................ . 10 .80 $5.00 \quad 4500$

WHITE SORTS.

Moore's Diamond 2 year No. I ................. . 5 I.00 6.00

" " I year No. I.............. . I0 .80 4.50

Niagara 2 year No. $1 \ldots \ldots \ldots \ldots \ldots \ldots \ldots \ldots \ldots \ldots$. I 5 I $00 \quad 6.00 \quad 50.00$

6 I year No. I...................... . . .80 $5.00 \quad 40.00$

Elvira 2 year No. I....................... . 5 I.00 500

" I year No. I...................... . I0 .So 400 


\section{RED OR AMBER SORTS.}

Fac's. Per ro. Per 100. Per 1000.

Catawba 2 year No. I................. \$o.15 \$1.00 $\$ 6.00$

" I year No. I.................. . 10 .80 4.50

Brighton 2 year No. I ................. . 5 1.00 7.00 $\$ 60 . c 0$

" I year No. I.................. . io .So 6.00 50.00

Delaware 2 year No. I.................. I5 I.00 7.00

Perkins 2 year No. I ...................... . I5 I.20 9.00

" I year No. I.................. I0 I.00 $\$ .00$

Agawam 2 year No. I ................... .15 I.00 5.00

" I year No. 1 $\ldots \ldots \ldots \ldots \ldots \ldots \ldots \ldots \ldots \ldots$.10 .75 4.00

Woodruff 2 year No. I ................... .20 1.50 I0.00

" 1 year No. I .................. I5 $1.20 \quad 9.00$

\section{BLACKBERRIES.}

Taylor and Ancient Briton

Per 10. Per ico. Per 1000.

Eldorado............................50 2.50 20.00

Snyder and Early Harvest...................... $20 \quad 2.00 \quad 12.00$

Minnewaski...........................50 2.50 IS.00

Mersereau ............................. 20 2.50 20.00

\section{RASPBERRIES.}

Cuthbert and Miller Red...

Per io. Per ioo. Per iooo.

Loudon and Columbian

.\$o.30

$\$ 1.50$

$\$ 10.00$

I. 50

10.00

Cumberland

$.30 \quad \mathrm{I} .50$

Io.co

Golden Queen

.30

I. $5 \mathrm{O}$

I0.00

$.50 \quad 2.00$

\section{DEWBERRIES.}

Lucretia...

Per io. Per ioo.

$\$ 0.50 \$ 2.00$

\section{STRAWBERRIES.}

Orders for Strawberry plants should be separate from Tree or Shrub orders and should always be sent by Express or Mail, at the proper time for planting. Special prices on large quantities.

Assorted varieties (for delivery after October 15 th Per 10. Per 10o. Per 1000. and in Spring rgo\$).................... \$o.30 \$1.00 \$5.00

Sample

Senator Dunlap.

Kansas (P.)
Clyde.

Bubach No. 5 .

Crescent (P)

Warfield. (P.)
Gandy.

Haverland (P.)

Marshall. 


\section{ASPARAGUS.}

Conover's, Palmetto and Columbian Mam. White 2 year No. I.

Per 10. Per 100. Per 1000.

\section{RHUBARB.}

Linnaeus (select strain) clumps................ \$0.25 \$2.co \$10.00

Fach. Per ro, Per 100. "6 6 " 6 sets...................... .15 $1.00 \quad 5.00$

\section{ORNAMENTAL DEPARTMENT.}

Our Ornamental Department is now one of the largest and most complete, (if not the largest) in the west. We invite careful perusal of our offerings and if possible, inpection of stock.

Special attention is given to the supplying of Public and Private Parks-, Estates, Subdivisions, Pleasure Grounds, Club Grounds, Railroad Companies for station grounds, etc.

On large lists of stock we request a list of wants for special prices.

We frequently have a few large specimen Trees and Shrubs in odd varieties; if the grades quoted are not large enough, kindly correspond with us, giving names of varieties wanted and size desired. We will then quote you a price on such as we can supply.

\section{DECIDUOUS TREES.}

Acer Dasycarpum (Silver or Soft Maple)

Each. Per io. Per roo.

Specimens, 6 in. in dia $\ldots \ldots \ldots \ldots \$ 10.00$

$\begin{array}{ll}66 & 66 \\ 66 & 66 \\ 66 & 66 \\ 66 & 66 \\ 66 & 66 \\ 66 & 66 \\ 66 & 66 \\ 66 & 16 \\ 66 & 66 \\ 66 & 66\end{array}$

\begin{tabular}{|c|c|c|c|c|c|}
\hline 6 & 5 to $5 \frac{1}{2}$ in. "6 & $\ldots \ldots \ldots \ldots$ & \multicolumn{3}{|l|}{$7 \cdot 50$} \\
\hline 6 & $4^{1 / 2}$ to 5 in 6 & ........... & \multicolumn{3}{|l|}{5.00} \\
\hline 66 & 4 to $4^{1 / 2}$ in. "6 & .......... & \multicolumn{3}{|c|}{4.00} \\
\hline 66 & $3^{1 / 2}$ to 4 in. " & ....... & \multicolumn{3}{|c|}{$3.00 \$ 27.50$} \\
\hline 66 & 3 to $3^{1 / 2}$ in. 6 & $\ldots \ldots \ldots \ldots$ & $2 \cdot 50$ & 22.50 & $\$ 200.00$ \\
\hline 66 & $2^{1 / 2}$ to 3 in. 66 & $\ldots \ldots \ldots \ldots$ & 2.00 & $17 \cdot 50$ & I 50.00 \\
\hline 86 & 2 to $21 / 2$ in. 6 & $\ldots \ldots \ldots \ldots$ & 1.50 & $12 \cdot 50$ & 100.00 \\
\hline 66 & $1^{3} / 4$ to 2 in. "6 & & 1.25 & 10.00 & So.00 \\
\hline 66 & & & 1.00 & $7 \cdot 50$ & 65.00 \\
\hline 66 & $0 t$ & 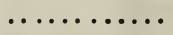 & .60 & 500 & 40.00 \\
\hline
\end{tabular}

Our stock of Silver or Soft Maple is by far

the largest and finest in the country.

“Plantanoides (Norway Maple) I2 to $14 \mathrm{ft}$.

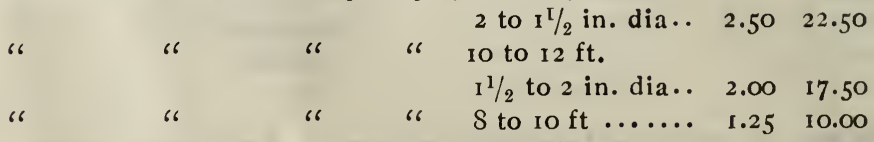


Acer Plantanoides var. Schwedlerii, (Purple Norway

Each. Per 10. Per 100.

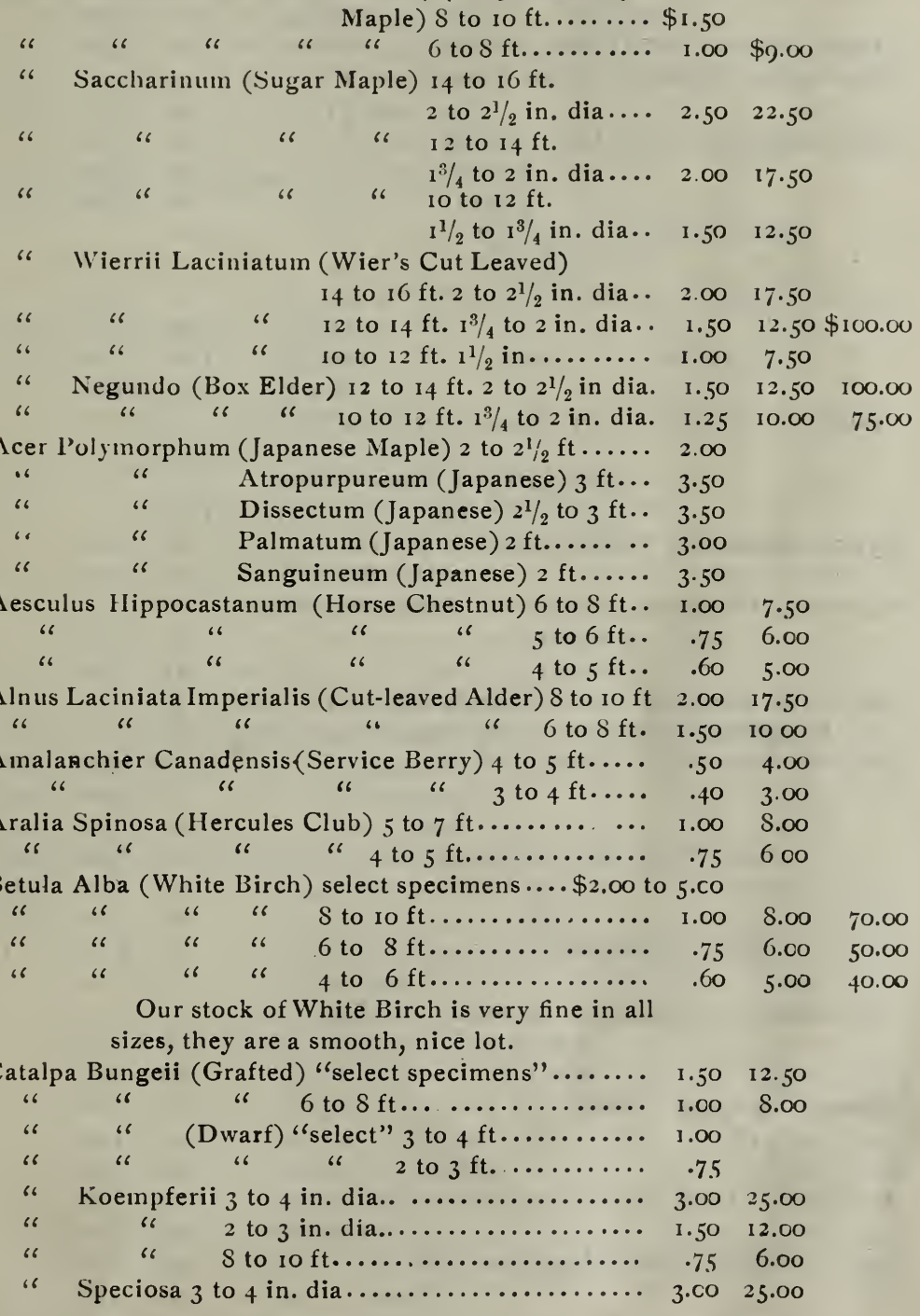


Catalpa Speciosa 2 to 3 in. dia................ \$I.50 $\$ 12.00$

" " $\quad S$ to ro $\mathrm{ft} \ldots \ldots \ldots \ldots \ldots \ldots \ldots \ldots \ldots . . .75 \quad 6.00$

Cerasus Avium Plena (Cherry double flg) 5 to $6 \mathrm{ft} \ldots$ I... $\quad$ 1.00 7.50

Chionanthus Virginica, (White Fringe) 3 to $+\mathrm{ft} \ldots \ldots$... 50 + 0

$$
\text { " " " " } 2 \text { to } 3 \mathrm{ft} \ldots \text {.... }
$$

.35

3.00

Cercis Canadensis (Red Bud) 6 to $8 \mathrm{ft} \ldots \ldots \ldots \ldots \ldots \ldots$........ $\quad$.00 $7.5^{\circ}$
"6
"6
"6 "6
4 to $6 \mathrm{ft}$
.60
5.00
"
"6 6
3 to $4 \mathrm{ft}$
.40
3.00
" Japonica (Japan) 2 to $2 \frac{1}{2} \mathrm{ft} \ldots \ldots \ldots \ldots \ldots \ldots \ldots$........ 1.00
"6 " " 8 to 24 in.............. 75
Cornus Florida (Dogwood) white flowering 4 to $5 \mathrm{ft}, \ldots \quad .75 \quad 6.00$
"6
"6
"6
" Rubra " "6
66
red
"6 3 to $4 \mathrm{ft}$...
.60
5.00
$1.50 \quad 12.50$
"
4 to $5 \mathrm{ft} \ldots$
3 to $4 \mathrm{ft}$...
1.2510 .00

Crataegus Oxycantha Flore Plena, (Flowering Thorn)

4 to $6 \mathrm{ft} . . . . . . .$. . 1.00

" " Coccinea Flore Plena "Paulii"

4 to $6 \mathrm{ft} \ldots \ldots \ldots \ldots$. 1.00

Cytisus Laburnum, (Golden Chain) 5 to $6 \mathrm{ft} \ldots \ldots \ldots . . .60$

4.00

" "6 " 4 to $5 \mathrm{ft} . . . . .$. .

$.40 \quad 3.00$

Euonymus Europaeus (Spindle or Strawberry tree)

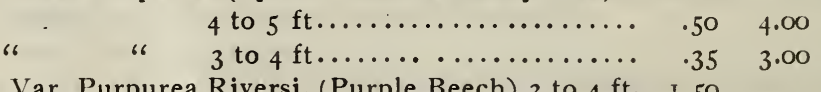

Fagus Var. Purpurea Riversi, (Purple Beech) 3 to $4 \mathrm{ft}$. I 50

"Feruginea (American Beech) 3 to $4 \mathrm{ft} \ldots \ldots \ldots \ldots . \quad .75$

Fraxinus Excelsior (European Ash) 2 to $21 / 2$ in ...... 1 .00

" " " " "

S.00 60.00

$6.00 \quad 50.00$

"6

"6

" $S$ to to $\mathrm{ft} . . . . . .$.

.60

5.00

40.00

"6

Alba (White Ash) I 2 to $14 \mathrm{ft} \ldots \ldots \ldots \ldots \ldots$

I. 00

8.00

60.00

"6

66

" Io to $12 \mathrm{ft}$...

.75

6.00

$-50.00$

"6

66

" 8 to io $\mathrm{ft}$

.60

500

40.00

6

Ornus (Flow

"6 "6

6 to $8 \mathrm{ft}$

.75

6.00

$.60 \quad 500$

Gymnocladus Canadensis (Kentucky Coffee Tree)

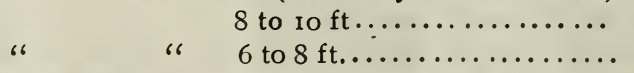

600

Halesia Tetraptera (Silver Bell) 5 to $6 \mathrm{ft} . \ldots \ldots \ldots \ldots$.
"6
"6
"6
" 4 to $5 \mathrm{ft}$
"

.50

500

.40

4.00

$\hat{3} \cdot 50$

Koelreuteria Paniculata (Varnish Tree) 8 to Io $\mathrm{ft} \ldots$.... I.5O I2.00 "6 "6

" 6 to $8 \mathrm{ft} \ldots . .$.

1.00

S. . O

Larix Europaeus (Larch European) 4 to $5 \mathrm{ft} \ldots \ldots \ldots \ldots .60 .60 .6 .60$ "

$.50 \quad 4.00$ 
Leriodendron Tulipefera (Tulip Tree) select speci-

E,ach. Per to. Per 100.

$\begin{array}{ll}66 & 66 \\ 66 & 66 \\ 66 & 66\end{array}$
mens, ro to ${ }_{5} \mathrm{ft} \ldots \ldots \ldots$..... 50 to 5.00

\begin{tabular}{|c|c|c|c|}
\hline 8 to ro $\mathrm{ft} . \ldots \ldots \ldots \ldots$ & 1.00 & $\$ 8.00$ & $\$ 60.00$ \\
\hline 6 to $S \mathrm{ft} . . . \ldots \ldots \ldots . . . .$. & .75 & 6.00 & 50.00 \\
\hline 5 to $6 \mathrm{ft}, \ldots \ldots \ldots \ldots \ldots$ & .60 & 5.00 & 40.0 \\
\hline 4 to $5 \mathrm{ft} . \ldots \ldots \ldots \ldots \ldots . . .$. & .50 & 4.00 & 30.0 \\
\hline
\end{tabular}

Liquidamber Styraciflua (Sweet Gum) select speci-

$\begin{array}{llll}6 & 66 & 6 & 66 \\ 6 & 66 & 66\end{array}$

$$
\begin{gathered}
\text { mens.... } \$ 2.50 \text { to } 5.00 \\
6 \text { to } 7 \mathrm{ft} \ldots . . . \text { I.00 }
\end{gathered}
$$

8.00 5 to $6 \mathrm{ft} \ldots \ldots . .75 \quad 6.00$ 4 to $5 \mathrm{ft} \ldots \ldots$.... $60 \quad 5.00$

40.00

Magnolia Accuminata 5 to $6 \mathrm{ft} \ldots \ldots \ldots \ldots \ldots \ldots \ldots$ I........... 8.00
"6

$$
4 \text { to } 5 \mathrm{ft}
$$
.75

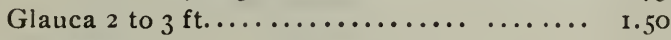

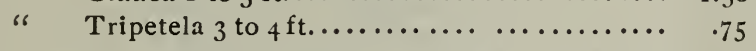

" Importen VARieties. Soulangeana, Lennei, Speciosa, Alexandrina, Alba Superba, Purpurea and Stellata, fine Imported Plants. (Spring I9oS Delivery only.)

4 to $5 \mathrm{ft}$. with ball of earth and well set with buds.... 3.00

3 to $4 \mathrm{ft}$. " " " " good number of buds........ 2.00

Paulonia Imperialis (Empress Tree) 5 to $6 \mathrm{ft} \ldots \ldots \ldots$. I.00 8.00 Persica (Peach double flowering) Red, Pink \& White
“
"6 “ 4 to $5 \mathrm{ft}$...... .35
300

Platanus Occidentalis (American Sycamore) 2 to $21 / 4$ in. dia................ 1.50

12.50

I 10.00

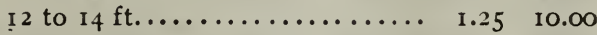
90.00 Io to $12 \mathrm{ft} . \ldots \ldots \ldots \ldots \ldots \ldots \ldots$ I. 1.00 $7 \cdot 50$ 60.00

6

$\mathrm{S}$ to io $\mathrm{ft}$... $.75 \quad 6.00$

" Orientalis (European Sycamore)

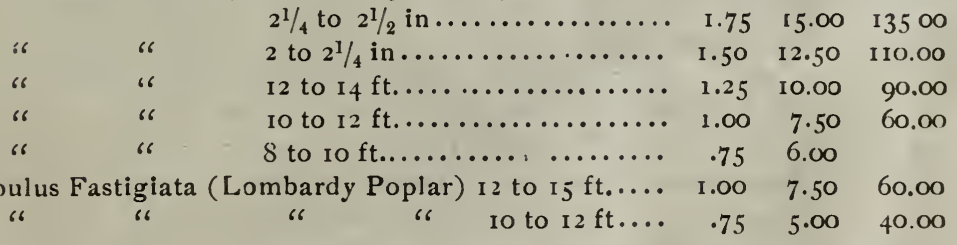


Fiach. Per Io. Per 100.

Populus Fastigiata (Lombardy Poplar) 8 to ro $\mathrm{ft} \ldots \ldots . \$ 0.50 \$ \$ 4.00$ \$30.0n

" Monolifera (Carolina Poplar) 5 to 6 in. select

\begin{tabular}{|c|c|c|c|c|c|c|c|}
\hline & & & & specimens & $5 \cdot \mathrm{m}$ & & \\
\hline 66 & “6 & 66 & 6 & 4 to 5 in. dia... & 4.00 & & \\
\hline 66 & 66 & "6 & 6 & 3 to 4 in. dia... & 2.50 & & \\
\hline 《6 & 66 & 66 & 6 & $2^{1 / 2}$ to 3 in ..... & 1.50 & 12.50 & \\
\hline 66 & 66 & 66 & 66 & 2 to $21 / 2$ in ..... & 1.00 & $7 \cdot 50$ & 60.00 \\
\hline 66 & 66 & "6 & 66 & Io to $12 \mathrm{ft} . .$. & $\cdot 7.5$ & 5.00 & 40.00 \\
\hline 6 & 66 & "6 & 66 & 8 to ro $\mathrm{ft} . . . .$. & $\cdot .50$ & 4.00 & 30.00 \\
\hline 66 & 66 & 6 & 66 & 6 to $8 \mathrm{ft} . . . .$. & .40 & 3.00 & 20.00 \\
\hline
\end{tabular}

" Nigra (Grecian Poplar) 5 to 6 in. dia. select

$\begin{array}{lll}66 & 66 & 66 \\ 66 & 66 & 66 \\ 66 & 66 & 66 \\ 66 & 66 & 66 \\ 66 & 66 & 66 \\ 66 & 66 & 66\end{array}$

" 4 to 5 in. dia. ...... 4.00

" 3 to 4 in. dia....... 2.50

"6 $21 / 2$ to 3 in. dia...... I.5O

" 2 to $2 \frac{1}{2}$ in. dia...... I.OO 7.50

60.00

"6 Io to $12 \mathrm{ft} \ldots \ldots \ldots \ldots \ldots . .75 \quad 5.00$

40.00

" $S$ to Io $\mathrm{ft} \ldots \ldots \ldots \ldots \ldots . .50 \quad 4.00$

30.00

"6 6 to $8 \mathrm{ft} . \ldots \ldots \ldots \ldots \ldots .40$

3.00

20.00

Alba Bolleana (Silver Poplar) io to $12 \mathrm{ft} \ldots .$. I.0 $9 \mathrm{co}$ "6 " " " " 6 to ro $\mathrm{ft} \ldots \ldots$.... $66 \quad 66$

"6

6

6 to $S \mathrm{ft} . . . . .40$

3.00

20.00

Monolifera Aurea (Golden Poplar) 8 to ro ft.. $\quad .75 \quad 6.00$

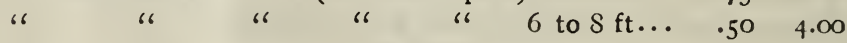

Prunus Pizzardi (Purple leaf Plum) 4 to $5 \mathrm{ft} \ldots \ldots \ldots . .35 \quad 3.00$

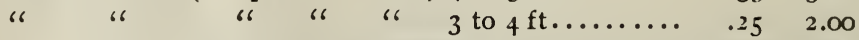

"6 Triloba (Plum double-flowering) 3 to $4 \mathrm{ft} \ldots . .4 .40 \quad 3.00$

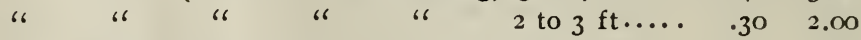

“ Padus (Bird Cherry) 4 to $6 \mathrm{ft} \ldots \ldots \ldots \ldots \ldots . . .50 \quad 4.00$

Pyrus Malus Augustifolia Plena (Bechtels double.

flowering Crab) 4 to $5 \mathrm{ft} \ldots \ldots \ldots \ldots .75 \quad 6.00$

Quercus Palustris (Pin Oak) $\&$ to Io $\mathrm{ft} \ldots \ldots \ldots \ldots \ldots . . \ldots$ I. 50 I2.50

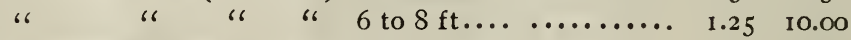

"6 Rubra (Red Oak) 8 to Io $\mathrm{ft} \ldots \ldots \ldots \ldots \ldots \ldots$ I........ 12.50

" "6 " " 6 to $8 \mathrm{ft} \ldots \ldots \ldots \ldots \ldots \ldots \ldots \ldots$ I.25 10.00

"6 Alba (White Oak) 5 to $6 \mathrm{ft} \ldots \ldots \ldots \ldots \ldots \ldots .25$

66 "6 "6 4 to $5 \mathrm{ft} \ldots \ldots \ldots \ldots \ldots \ldots$..0

"6 Macrocarpa (Mossy cup or Burr) 7 to $S \mathrm{ft} . . . \quad$ I.5O

66 66 66 66 "6 6 to $7 \mathrm{ft} . . .1 .25$

Robinia Hispida (Flowering Locust) 4 to $5 \mathrm{ft} \ldots \ldots \ldots .75$ 
Salisburia Adiantifolia (Ginkgo or Maiden IIair)

Fiach. Perio. Perion.

\begin{tabular}{|c|c|c|c|c|c|c|c|c|c|}
\hline & & & & & $S$ to & Io $\mathrm{ft}$. & 1.00 & $\$ S .00$ & $\$ 70.00$ \\
\hline 6: & 66 & 6 & 66 & 6 & 6 to & $S \mathrm{ft}$. & .75 & 6.00 & 50.00 \\
\hline & 66 & 66 & 66 & 66 & 5 to & $6 \mathrm{ft}$. & .60 & 5.00 & 10.00 \\
\hline
\end{tabular}

Another grand tree that is fast coming to the front, both as a lawn and street tree.

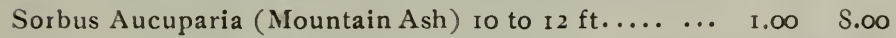

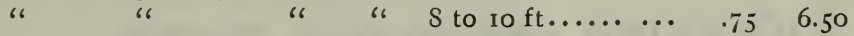

" " " " 6 to $S \mathrm{ft} \ldots \ldots \ldots . .60 \quad 5.00$

" Pinnatifida (Oak Leaved Mt. Ash) 6 to $8 \mathrm{ft} \ldots$... $75 \quad 6.00$

4000

" " " " " " 5 to $6 \mathrm{ft} \ldots$... 60 5.00

Salix (Willow) Gold Bark 5 to $6 \mathrm{ft} \ldots \ldots \ldots \ldots \ldots \ldots \ldots . .6 \%$

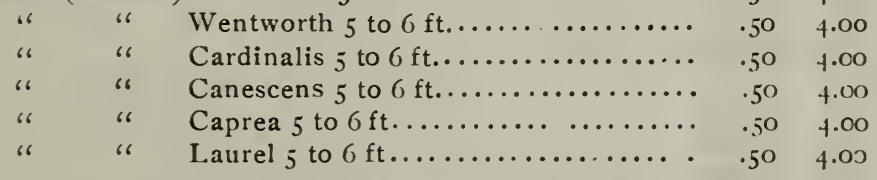

Taxodium Distichum (Cypress) select specimens

\begin{tabular}{|c|c|c|c|c|c|c|}
\hline & & & $\$ 2.00 \mathrm{t}$ & $5 \cdot \mathrm{CO}$ & & \\
\hline 66 & 6 & "6 & 6 to $7 \mathrm{ft} . . . . . . .$. & 1.25 & 10.00 & \\
\hline 66 & " & 66 & 5 to $6 \mathrm{ft} \ldots \ldots \ldots$ & .90 & S.oo & \\
\hline & ، & "6 & 4 to $5 \mathrm{ft} \ldots \ldots \ldots$ & .75 & 6.00 & \\
\hline
\end{tabular}

This grand tree should be more extensively planted in Parks and Private grounds; it is perfectly hardy with us here at St. Louis.

Tilia $\Lambda$ mericana (American Linden) I 2 to I $_{4} \mathrm{ft} \ldots . .22 .00$

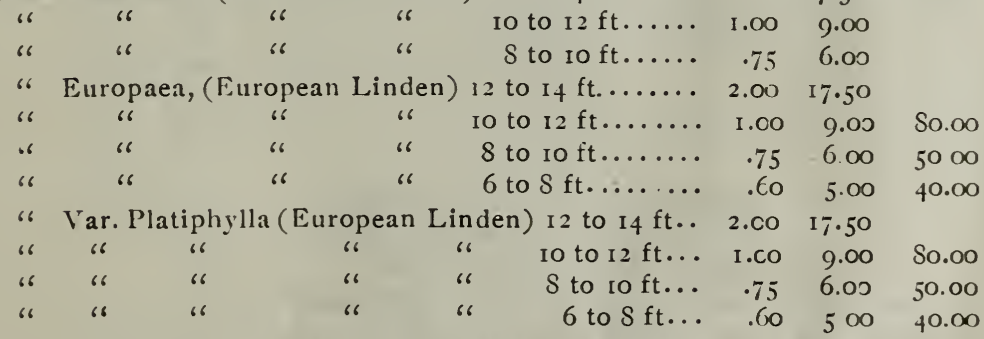

Ulmus Americana (American Elm) select specimens,

$3^{1 / 2}$ to 6 in. dia. $\$ 3.50$ to 15.00

$\begin{array}{ll}66 & 66 \\ 66 & 66 \\ 66 & 66 \\ 66 & 66\end{array}$

$21 / 2$ to 3 in............ 2.00

2 to $21 / 2$ in............ 1.25

10.0090 .00

Io to $12 \mathrm{ft} \ldots \ldots \ldots \ldots$........ I.00 $7.50 \quad 65.00$

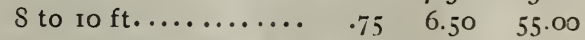


Ulmus Campestre (English Elm) select specimens,

Fiach. Per io. Per ioo.

$\begin{array}{lll}66 & 66 & 66 \\ 66 & 66 & 66 \\ 66 & 66 & 66 \\ 66 & 66 & 66 \\ 66 & 66 & 66\end{array}$

$3^{1 / 2}$ to 5 in. dia. $\$ 3.50$ to 15.00

$2^{1 / 2}$ to 3 in............ 2.00

I 2 to $14 \mathrm{ft} \ldots \ldots \ldots \ldots$ I. 50 I0.00

Io to $12 \mathrm{ft} \ldots \ldots \ldots \ldots$, t.00 8.00

8 to ro $\mathrm{ft} . \ldots \ldots \ldots \ldots$. So 7.00

70.00

6 to $8 \mathrm{ft} \ldots \ldots \ldots \ldots . .50 \quad 5.00 \quad 40.00$

\section{WEEPING DECIDUOUS TREES.}

Acer Wierrii Laciniatum(Maple Cut-leaved) I 2 to I $4 \mathrm{ft}$.. \$1.50 \$1 2.50

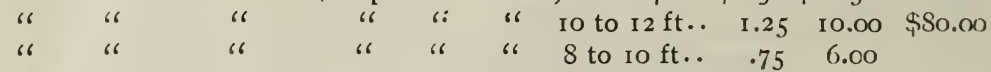

Betula Alba Laciniata Pendula (Birch Cut-leaved)

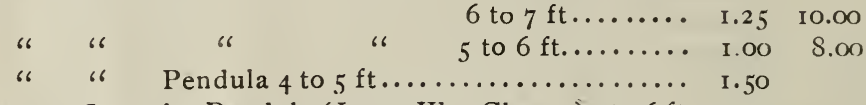

Cerasus Japonica Pendula (Japan W p. Cherry) 5 to $6 \mathrm{ft} . \quad 1.25$

Fraxinus Excelsior Pendula (Wp. Mt. Ash) 2 year heads 1.00

Morus Tartarica Pendula (Tea's Weeping Mulberry) select 2 year heads, grafted 5 to $6 \mathrm{ft}$. $1.50 \quad 13.00$

" " Pendula (Tea's Weeping Mulberry) medium 2 year heads, grafted 4 to $6 \mathrm{ft}$. I.25 I0.00

" " Pendula (Tea's Weeping Mulberry)

No. I one year heads, grafted 5 to $6 \mathrm{ft}$. $\quad$ I.25 $\quad$ I0.00

Salix (Willow) Babylonica 6 to $8 \mathrm{ft} . \ldots \ldots \ldots \ldots \ldots \ldots . .5 \% \quad .50 \quad 4.00$

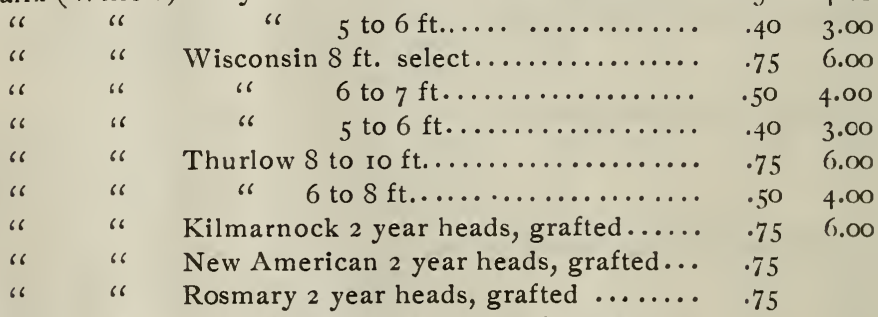

I'lmus Var. Camperdown: Pendula (Camperdown Weeping Elm) 2 year heads, grafted 6 to $7 \mathrm{ft} . .$. r.oo $\quad 9.00$

\section{ORNAMENTAL SHRUBS.}

Amygdalus Rosea and Alba plena, (Almond double-

Each. Per io, Per roo. flowering Red and White) $3 \mathrm{ft}$., 2 year old $\$ 0.35 \quad \$ 3.00 \quad \$ 25.00$ " Rosea and Alba plena, (Almond double-

$\begin{array}{lllll}\text { "flow. Red and White) } 2 \text { to } 3 \mathrm{ft} \text {., I year old } & .30 & 2.50 & 20.00\end{array}$ 
Each. Per 10. Per 100.

$\Lambda$ morpha Canescens 18 to 24 in $\$ 0.25 \$ 2.00$

" Fruticosa 5 to $6 \mathrm{ft}$.

$.50 \quad 4.00 \quad \$ 30.00$ "r 3 to 4

$.35 \quad 3.00$ 20.00 Aralia Pentaphylla 3 to $3 \frac{1}{2} \mathrm{ft}$ $.40 \quad 3.00$ 25.00 Azalia Mollis $1 S$ to $2 f$ in. (Named Varieties) imported, Spring $190 S$ delivery; dormant ......... 66 Pontica (Ghent) is to 24 in. (Named Varieties) Imported, Spring igoS delivery........... Baccharis Halimifolia 3 to $4 \mathrm{ft} \ldots \ldots \ldots \ldots \ldots \ldots \ldots$

$1.5012 .50 \quad 100.00$

$1.5012 .50 \quad 100.00$ $.35 \quad 3.00 \quad 20.00$ 66

$$
66
$$

2 to $21 / 2 \mathrm{ft} \ldots \ldots \ldots \ldots \ldots \ldots \ldots \ldots \ldots$

$.30 \quad 2.50$ I 8.00 "6

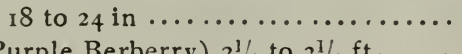

Berberis Purpurea (Purple Berberry) $2^{1 / 2}$ to $3^{1 / 2} \mathrm{ft} \ldots \ldots$. $.20 \quad 1.50$ I0.00 $.35 \quad 3.60 \quad 20.00$

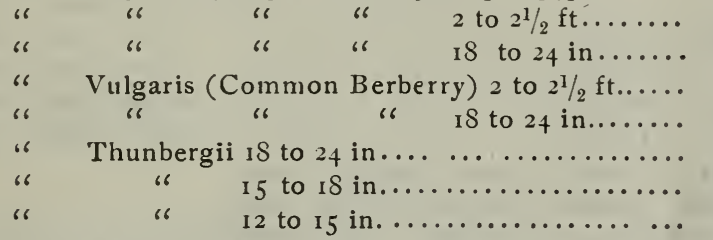
$.30 \quad 2.50$ $.20 \quad 1.50 \quad 10.00$ $\begin{array}{lll}.30 & 2.50 \quad 17.00\end{array}$ $.20 \quad 1.50 \quad 10.00$ $\begin{array}{lll}.30 & 2.50 & 20.00\end{array}$ $.25 \quad 2.00 \quad 15.00$ $\begin{array}{lll}.20 & 1.50 & 12.00\end{array}$

Calycanthus Floridus 2 to $3 \mathrm{ft} . \ldots \ldots \ldots \ldots \ldots \ldots \ldots \ldots \ldots .30 \quad 2.50$ 20.co

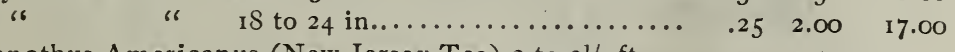

$\begin{array}{lllll}\text { Ceanothus Americanus (New Jersey Tea) } 2 \text { to } 2 \frac{1}{2} \mathrm{ft} . \ldots & \cdot 30 & 2.50\end{array}$ "6 "6 "6 " is to 24 in.... Clethra Alnifolia (Sweet Pepper) 2 to $21 / 2 \mathrm{ft} . \ldots \ldots \ldots$. $.25 \quad 2.00$ .353 .00 $.30 \quad 2.50$

Caryopteris Mastacanthus (Blue Spirea) is to 24 in.... $.25 \quad 2.00$ $.50 \quad 4.00$

$.35 \quad 3.00$

15.00 Cornus Mascula (Cornelian Cherry) 4 to $5 \mathrm{ft}$., bushy...

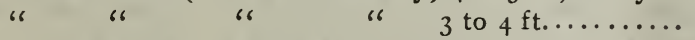
" Sanguinea (Red Ozier) 3 to $4 \mathrm{ft} \ldots \ldots \ldots \ldots \ldots$ "6 " "6 " 2 to $3 \mathrm{ft} \ldots \ldots \ldots \ldots \ldots \ldots$ .353 .00 30.00 2000 $.30 \quad 2.50$ 25.00 20.00 " Siberica (Siberian Red Ozier) 3 to $4 \mathrm{ft} \ldots \ldots \ldots$. " " " " " 2 to $3 \mathrm{ft} . \ldots \ldots \ldots$. "Elegantissima Variegata (White margined $.35 \quad 3.00 \quad 25.00$ $\begin{array}{lll}.30 & 2.50 \quad 20.00\end{array}$ "6 " 6 " Red Ozier) 3 to $4 \mathrm{ft} . \ldots \ldots$. 2 to $3 \mathrm{ft} . \ldots \ldots \ldots \ldots$ " Spaethii (Yellow margined Red Ozier) 2 to $3 \mathrm{ft}$. $.50 \quad 4.00$ $.40 \quad 3.00$ $.50 \quad 4.00$ $.40 \quad 3.00$ "Stolonifera (Wild Red Ozier) 4 to $5 \mathrm{ft}$., bushy.. $\begin{array}{lll}.40 & 3.50 \quad 25.00\end{array}$ $.30 \quad 2.50 \quad 20.00$

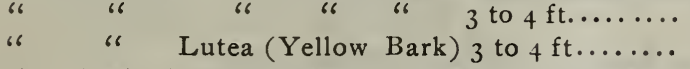
$.40 \quad 3.50$ Corylus Avel. Atropurpurea (Purple Lvd. Filbert) 2 to $2 \mathrm{l} / 2 \mathrm{ft} \ldots \ldots \ldots \ldots \ldots$ 66 66 Is to 24 in. 
Each. Per 10. Per 100.

Coronilla Emerus (Scorpion Senna) 2 to $3 \mathrm{ft} \ldots \ldots \ldots . \$ 0.35 \$ 3.00$

Cydonia Japonica (Fire Bush) 2 to $3 \mathrm{ft}$.

$.30 \quad 2.50 \quad \$ 2000$

" " " " 6 is to 24 in.............

$.25 \quad 2.00 \quad 15.00$

Colutea Arborescens (Bladder Senna) 4 to $5 \mathrm{ft} . \ldots$. .

$\begin{array}{lll}.40 & 3.50 & 30.00\end{array}$

" " $"$ " $\quad$ " $\quad$ " 3 to $4 \mathrm{ft} \ldots \ldots \ldots \ldots$

$.35 \quad 3 . \mathrm{CO} \quad 25.00$

$.30 \quad 2.30 \quad 20.00$

Desmodium Penduliflorum-strong clumps......... . .50 4.00

Deutzia Crenata, Crenata Plena, Candidissima, Scabra,

Watererii, Wellsii, Pride of Rochester.

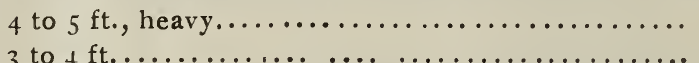

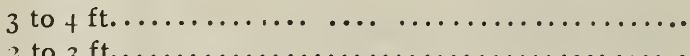

.504 .0 in 30.00

$.35 \quad 3.00 \quad 25.00$

$.25 \quad 2.00 \quad 17.00$

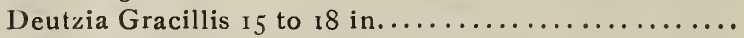

$\begin{array}{lll}.30 & 2.50 \quad 20.00\end{array}$

$\begin{array}{lll}.25 & 2.00 \quad 15.00\end{array}$

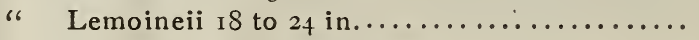

$.30 \quad 250 \quad 20.00$

$.25 \quad 2.00 \quad$ I 5.00

Diervilla (Weigelia), Amabilis Alba, Candida, Rosea,

Desboiseii, Lavellei, Gustave Mallet, Stelznerii, Floribunda, Verschafelti, Van Houtte,

Gigantoeflora 3 to $4 \mathrm{ft} . \ldots \ldots \ldots \ldots \ldots \ldots \ldots$.

2 to $3 \mathrm{ft} . \ldots \ldots \ldots \ldots \ldots \ldots \ldots \ldots$

"6 Rosea Nana Variegata, Eva Rathke, Koster-

$.35 \quad 3.00$

25.00

$.3 \mathrm{O} \quad 2.5 \mathrm{O} \quad 2 \mathrm{O} \mathrm{CO}$

iana Variegata, Edward Andre, Abel Carriere.

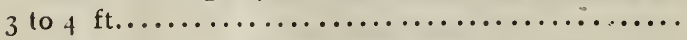

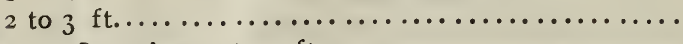

Eleagnus Longipes 2 to $3 \mathrm{ft}$..

$.35 \quad 3.00$

$.30 \quad 2.50$

$.35 \quad 3.00$

$.30 \quad 2.50$

25.00

" 18 to 24 in $\ldots \ldots \ldots \ldots \ldots \ldots \ldots \ldots$

" Angustifolia 4 to $5 \mathrm{ft} \ldots \ldots \ldots \ldots \ldots \ldots \ldots$

$.40 \quad 3.50$

$\begin{array}{ll}.30 & 2.50\end{array}$

66

"6 3 to

$.50 \quad 4.00$

$.35 \quad 3.00$

25.00

$\begin{array}{ll}.30 & 2.50\end{array}$

20.00

Forsythia (Golden Bell) Fortunii, Suspensa, Viridissima, Intermedia, 3 to $4 \mathrm{ft} . \ldots \ldots \ldots \ldots \ldots$

2 to $3 \mathrm{ft} \ldots \ldots \ldots \ldots$

$.35 \quad 3.00 \quad 25.00$

$\begin{array}{lll}.30 & 2.50 & 20.00\end{array}$

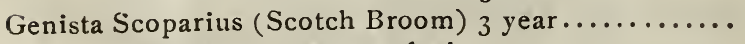

$.35 \quad 3.00$

.353 .00

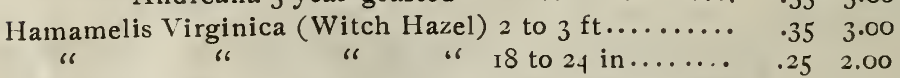

Hibiscus (Althea or Rose of Sharon) Ardens, Boule

De Feu, Leopoldii, Pompon Rouge, Pulcherima,

Coelestis, $\Lambda$ lba Plena, Rubra, Purpurea, Variega.

ted, Anemoneflora, Bicolor, Duchesse de Brabant, 
Elegantissima, Jean de Arc, Lady Stanley, Paeo-

Each. Per 10. Per Ioo.

niflora, Renunculoeflora plena 3 to $4 \mathrm{ft} \ldots \ldots \ldots \ldots \ldots$..... \$0.30 \$2.50 \$20.co

2 to $3 \mathrm{ft} \ldots \ldots \ldots \ldots . .25 \quad 2.00 \quad 15.00$

Hydrangea Paniculata Grandiflora 3 to $3 \frac{1 / 2}{\mathrm{ft}} \ldots \ldots \ldots \ldots .40 .40$. 3.50 30.co

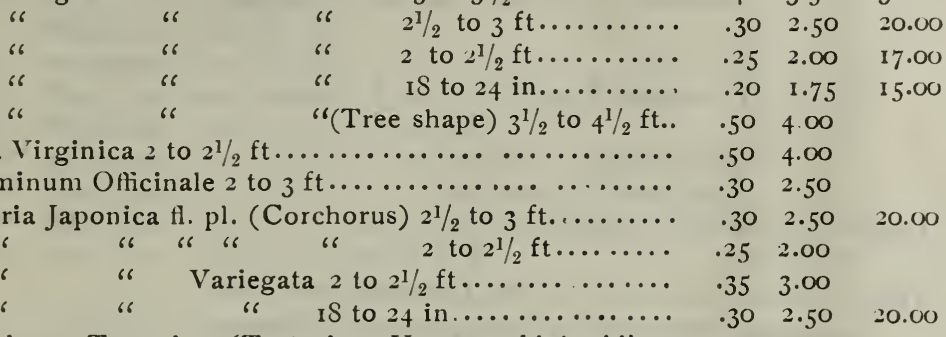

Lonicera Tartarica (Tartarian Honeysuckle) Alba,

Fragrantissima, Morrowii, Rubra Grandiflora,

Rosea, Virginalis Rubra 3 to $4 \mathrm{ft} \ldots \ldots \ldots \ldots \ldots$.......... $35 \quad 3.00 \quad 25.00$

$2^{1 / 2}$ to $3 \mathrm{ft} \ldots \ldots \ldots \ldots \ldots \ldots . .30 \quad .30 \quad 2.50 \quad 20.00$

2 to $21 / 2 \mathrm{ft} \ldots \ldots \ldots \ldots \ldots \ldots \ldots \ldots . .25 \quad .2 .00 \quad 15.00$

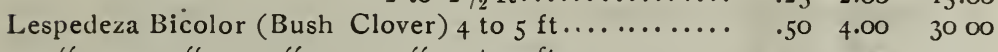

$\begin{array}{lllllllll}" \text { " } & \text { "6 } & \text { " } & 3 & \text { to } 4 \mathrm{ft} \ldots \ldots \ldots \ldots \ldots & .40 & 3.00 & 20.00 \\ & & & 2 & \text { to } 3 \mathrm{ft} \ldots \ldots \ldots \ldots & .30 & 2.00 & 15.00\end{array}$

Ligustrum Ovalifolium (Privet California)

Each. Per 10. Per 100. Per 1000.

\begin{tabular}{|c|c|c|c|c|c|}
\hline & 3 to $4 \mathrm{ft} . \ldots \ldots \ldots \ldots$ & 0.30 & $\$ 2.00$ & $\$ 12.00$ & \\
\hline 66 & $2^{1 / 2}$ to $3 \mathrm{ft} . \ldots \ldots \ldots$ & .25 & I.75 & 10.00 & $\$ 75.00$ \\
\hline 66 & 2 to $2^{i} / 2$ ft......... & .20 & 1.50 & 8.00 & 60.00 \\
\hline "6 & IS to 24 in............ & .15 & 1.00 & 5.00 & 35.00 \\
\hline 《6 & ${ }_{5} 5$ to 18 in $\ldots \ldots \ldots \ldots$ & .10 & .75 & $3 \cdot 50$ & 2500 \\
\hline
\end{tabular}

Our stock of this popular hedge is a very large one, comprising about 200,000 plants in all sizes. All our Privets are transplanted after the first season's growth, which makes them strong, bushy and well rooted, no better Privet grown anywhere. Special prices on large quantities.

Each. Per Io. Per 100.

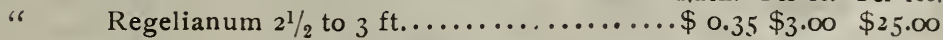

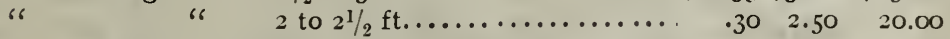

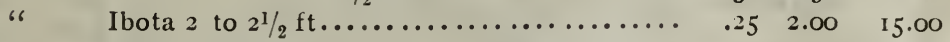

" " IS to $24 \mathrm{in} \ldots \ldots \ldots \ldots \ldots \ldots \ldots \ldots . .20 \quad 1.50 \quad 10.00$

" Sinensis Nana (Dwarf) 3 to $3^{1 / 2} \mathrm{ft} \ldots \ldots \ldots . .35 \quad 3 . \mathrm{co}$

"6 "6 " 2 to $3 \mathrm{ft}, \ldots \ldots \ldots \ldots$. . $30 \quad 2.50$

Pavia Macrostachia 18 to $2+$ in.................. 1.00 
Philadelphus (Syringa or Mock Orange)

Each. Per 10. Per 100.

Coronarius and Grandiflorus, 3 to $4 \mathrm{ft} \ldots \ldots 0.35 \$ 3.00 \quad \$ 25.00$

"Coronarius Follis Aureis (Golden)

"6 "6 " 615 to 18 in..

" Lemoineii Erectus $2^{3 / 2}$ to $3 \mathrm{ft}$., heavy.....

"6 "6 " 2 to $21 / 2 \mathrm{ft} \ldots \ldots \ldots \ldots$

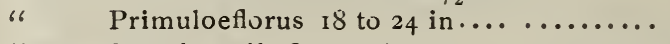

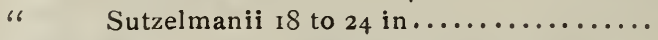

Potentilla Fruticosa (Cinquifoil) 2 to $3 \mathrm{ft}$..................

" " " 18 to 24 in............

Ribes (Currant) Aureum, Alpina, Gordonianum, Sanguineum Flora Plena, Sanguineum Albidum.

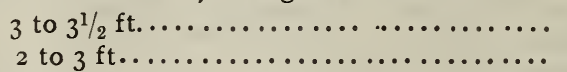

Rhodotypus Kerrioides (White Kerria) $2^{1 / 2}$ to $3 \mathrm{ft} \ldots$... "6 "6 " 18 to 24 in......

Rhus Cotinus (Purple Fringe) 5 to $6 \mathrm{ft} \ldots \ldots \ldots \ldots \ldots \ldots$

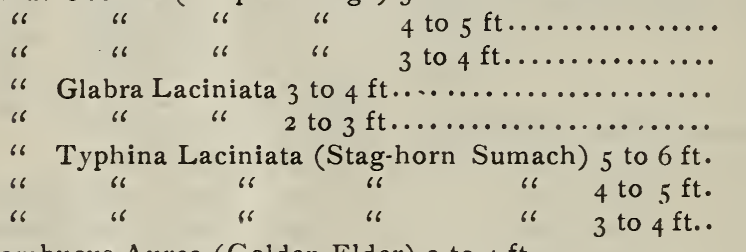

Sambucus Aurea (Golden Elder) 3 to $4 \mathrm{ft} \ldots \ldots \ldots \ldots \ldots$.

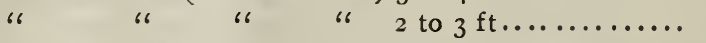

Sambucus Variegated 3 to $4 \mathrm{ft} \ldots \ldots \ldots \ldots \ldots \ldots \ldots \ldots . . . . . .$.

$\cdot 35 \quad 3$ Co

$.30 \quad 2.50$

$.30 \quad 2.50$

$.25 \quad 2.00$

$.50 \quad 4.50$

$.40 \quad 3.50$

$\begin{array}{ll}.30 & 2.50\end{array}$

$.50 \quad 4.00$

$.35 \quad 3.00$

$.50 \quad 4.00$

$.35 \quad 3 . \mathrm{co}$

$\begin{array}{ll}.30 & 2.50\end{array}$

$\begin{array}{lll}.35 & 3.00 & 25.00\end{array}$

$\begin{array}{llll}.30 & 2.50 & 20.00\end{array}$

$\begin{array}{lll}.35 & 3.00 \quad 25.00\end{array}$

$\begin{array}{lll}.30 & 2.50 & 20.00\end{array}$

$\begin{array}{lll}.35 & 3.00 & 25.00\end{array}$

$\begin{array}{lll}.30 & 2.50 & 20.00\end{array}$

$\begin{array}{lll}.30 & 2.50 & 2000\end{array}$

$\begin{array}{lll}.25 & 2.00 \quad 17.00\end{array}$

$\begin{array}{lll}.35 & 3.00 \quad 2500\end{array}$

$\begin{array}{lll}.30 & 2.50 & 20.00\end{array}$

$\begin{array}{lll}.30 & 2.50 & 20.00\end{array}$

$\begin{array}{lll}.25 & 2.00 & 17.00\end{array}$

$\begin{array}{lll}.35 & 3.00 & 25 . \mathrm{CO}\end{array}$

$\begin{array}{lll}.30 & 2.50 & 20.00\end{array}$

$\begin{array}{lll}.40 & 3.50 & 30.00\end{array}$

.35 3.लO 25.00

$\begin{array}{lll}.30 & 2.50 & 20.00\end{array}$

$.35 \quad 3.00 \quad 25.00$ 
Each. Per ro. Per 100.

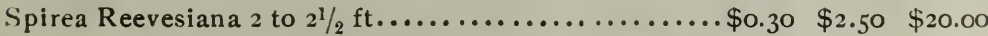

\begin{tabular}{|c|c|c|c|c|}
\hline 66 & fl. pl. $2^{1 / 2}$ to $3 \mathrm{ft} \ldots \ldots \ldots \ldots \ldots \ldots$ & $\cdot 35$ & 3.00 & 25.00 \\
\hline 66 & " $\quad$ " $" 2$ to $21 / 2 \mathrm{ft} \ldots \ldots \ldots \ldots \ldots \ldots \ldots$ & $\cdot 30$ & $2 \cdot 50$ & 20.00 \\
\hline 66 & Billardii $21 / 2$ to $3 \mathrm{ft} \ldots \ldots \ldots \ldots \ldots \ldots \ldots \ldots$ & $\cdot 30$ & 2.50 & 20.00 \\
\hline 66 & Douglassii $2^{1 / 2}$ to $3 \mathrm{ft} \ldots \ldots \ldots \ldots \ldots \ldots \ldots \ldots$ & $\cdot 30$ & $2 \cdot 50$ & 20.00 \\
\hline 66 & 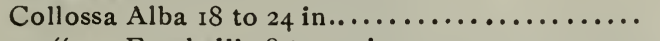 & $\cdot 30$ & $2 \cdot 50$ & \\
\hline 66 & 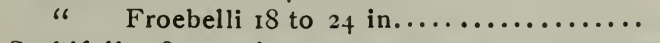 & $\cdot 30$ & $2 \cdot 5^{0}$ & \\
\hline 66 & 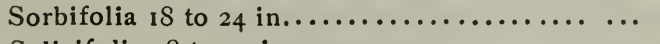 & $\cdot 30$ & $2 \cdot 50$ & \\
\hline 66 & Salicifolia 18 to 24 in $\ldots \ldots \ldots \ldots \ldots \ldots \ldots \ldots$ & $\cdot 30$ & $2 \cdot 50$ & \\
\hline 6 & Opulifolia 3 to $4 \mathrm{ft} . \ldots \ldots \ldots \ldots \ldots \ldots \ldots \ldots$ & $\cdot 35$ & 3.00 & 25.00 \\
\hline "6 & 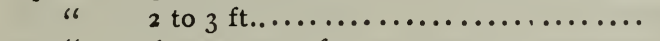 & $\cdot 30$ & 2.50 & 20.00 \\
\hline 66 & Aurea 3 to $4 \mathrm{ft} \ldots \ldots \ldots \ldots \ldots \ldots$ & $\cdot 35$ & 3.00 & 25.00 \\
\hline 66 & " $\quad$ " 2 to $3 \mathrm{ft} \ldots \ldots \ldots \ldots \ldots \ldots$ & $\cdot 30$ & $2 \cdot 50$ & 20.00 \\
\hline 66 & Multiflora Arguta 2 to $21 / 2 \mathrm{ft} \ldots \ldots \ldots \ldots \ldots \ldots$ & $\cdot 35$ & 3.00 & 25.00 \\
\hline 6 & 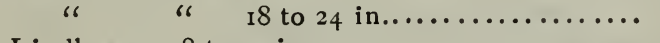 & $\cdot 30$ & $2 \cdot 50$ & 20.00 \\
\hline 66 & Lindleyana 18 to 24 in $\ldots \ldots \ldots \ldots \ldots \ldots \ldots$ & $\cdot 30$ & 2.50 & \\
\hline 66 & Lanceolata 18 to 24 in $\ldots \ldots \ldots \ldots \ldots \ldots \ldots \ldots$ & $\cdot 30$ & 2.50 & \\
\hline 66 & 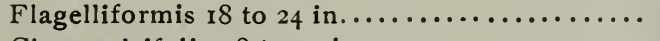 & $\cdot 30$ & 2.50 & \\
\hline 6 & 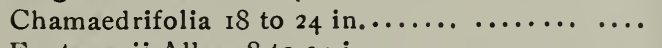 & $\cdot 30$ & 2.50 & \\
\hline & $\begin{array}{l}\text { Fonteneyii Alba } 18 \text { to } 24 \text { in................. } \\
\text { ga (Lilac) Vulgaris. }\end{array}$ & .30 & $2 \cdot 50$ & \\
\hline 66 & (Common Blue) 4 to $5 \mathrm{ft}$ heavy $\ldots \ldots \ldots \ldots \ldots$ & $.5^{0}$ & 4.00 & \\
\hline 66 & " $\quad$ s 3 to $4 \mathrm{ft} \ldots \ldots \ldots \ldots \ldots \ldots$ & $\cdot 35$ & 3.00 & 25.00 \\
\hline 66 & " $\quad$ " 2 to $3 \mathrm{ft} \ldots \ldots \ldots \ldots \ldots \ldots$ & 30 & 2.50 & 20.00 \\
\hline 6 & Alba (Common White) 2 to $3 \mathrm{ft} . \ldots \ldots \ldots \ldots$ & $\cdot 30$ & $2 \cdot 50$ & \\
\hline 6 & Persica Rubra (Persian Red) 3 to $31 / 2 \mathrm{ft} \ldots \ldots$. & $\cdot 35$ & $3 . \mathrm{CO}$ & 25.00 \\
\hline 66 & "6 6 " 62 to $3 \mathrm{ft} . \ldots \ldots$ & .30 & 2.50 & 20.00 \\
\hline 6 & Alba (Persian White) 3 to $3^{1 / 2} \mathrm{ft} . \ldots \ldots$ & $\cdot 35$ & 300 & 25.00 \\
\hline 66 & " $6 \quad 6 \quad 6 \quad 2$ to $3 \mathrm{ft} . \ldots \ldots$ & $\cdot 30$ & 2.50 & 20.00 \\
\hline 66 & Rhotomagensis Rubra (Rouen) 3 to $4 \mathrm{ft}$...... & $\cdot 35$ & 3.00 & 25.00 \\
\hline 66 & $66 \quad 66 \quad 2$ to $3 \mathrm{ft} . \ldots \ldots$ & $\cdot 3^{\circ}$ & 2.50 & 20.00 \\
\hline 66 & Josikaea (Hungarian) 3 to $4 \mathrm{ft} . \ldots \ldots \ldots \ldots$ & $\cdot 35$ & 3.00 & 25.00 \\
\hline 66 & " $" \quad 2$ to $3 \mathrm{ft} . \ldots \ldots \ldots \ldots$ & $\cdot 30$ & 2.50 & 20.00 \\
\hline 66 & Japonica (Japan) 3 to $4 \mathrm{ft} . . \ldots \ldots \ldots \ldots \ldots$ & .40 & $3 \cdot 50$ & 30.00 \\
\hline "6 & "6 $\quad$ is 2 to $3 \mathrm{ft} \ldots \ldots \ldots \ldots \ldots \ldots$ & $\cdot 35$ & 3.00 & 25.00 \\
\hline 66 & I 8 to 24 in............... & $\cdot 30$ & 2.50 & 20.00 \\
\hline 66 & 3 to $4 \mathrm{ft} . \ldots \ldots \ldots \ldots \ldots \ldots$ & .40 & $3 \cdot 5^{\circ}$ & 30.00 \\
\hline 66 & 2 to $3 \mathrm{ft} . \ldots \ldots \ldots \ldots \ldots \ldots$ & $\cdot 35$ & 3.00 & $25 . \mathrm{CO}$ \\
\hline 66 & $" 6 \quad r 8$ to 24 in................... & $\cdot 30$ & 2.50 & \\
\hline "6 & $\begin{array}{l}\text { Imported Single and Double Sorts, very } \\
\text { fine Varieties; Alphonse Lavellei, Belle de } \\
\text { Nancy, La Tour de Auvergne, Emile Le- } \\
\text { moine, Mad. Abel de Chatenay, Mad. Le- } \\
\text { moine, Pres. Carnot, Pres. Grevy, Leon }\end{array}$ & & & \\
\hline
\end{tabular}


Syringa-(Continued.)

Fiach. Per 10. Per Ioo.

Simon, Mad. Casimir Perier, Michel Buchner, Ludwig Spaeth, La Mauve, Chas. the

Tenth, Mad. Jules Finger, 4 to $5 \mathrm{ft} \ldots \ldots \ldots \ldots . \$ 0.50$ \$4.00 $\$ 3500$

66

66

66
3 to $4 \mathrm{ft} \ldots \ldots \ldots \ldots .40$

2 to $3 \mathrm{ft} . \ldots \ldots \ldots \cdot 35$

I to $2 \mathrm{ft} . \ldots \ldots \ldots . . . .30$
$3.50 \quad 30.00$

$3.00 \quad 2500$

$2.50 \quad 20.00$

Our stock of old and new varieties of Lilacs

is a fine one, this popular Shrub should

be more extensively planted, especially the newer sorts.

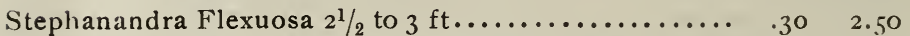

Symiphoricarpus Racemosus $2 \frac{1}{2}$ to $3 \mathrm{ft} \ldots \ldots \ldots \ldots . . . .30 \quad 2.50$

\section{6}

66

66

66
"6

Vulgar

2 to $2 \frac{1}{2} \mathrm{ft}$

to $3 \mathrm{ft}$.

2 to $21 / 2 \mathrm{ft}$

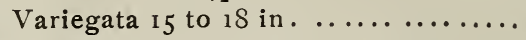

Tamerix Africana, Gallica, Indica and Tetandra pur-

purea 4 to $5 \mathrm{ft} . \ldots \ldots \ldots \ldots \ldots \ldots \ldots \ldots \ldots \ldots$

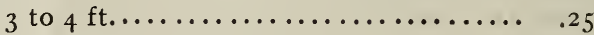

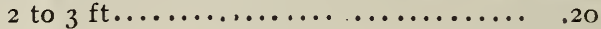

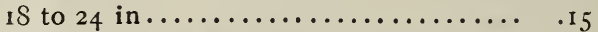

$.25 \quad 2.00$

$.30 \quad 2.50$

$.25 \quad 2.00$

$.25 \quad 2.00$

20.00

$17 . \mathrm{co}$

20.0n

17.00

$30 \quad 2.50$

20.00

$2.00 \quad 15.00$

I. $50 \quad 10.00$

1.00

5.00

Hispida Estavalis (New) 2 to $2 \frac{1}{2} \mathrm{ft} \ldots \ldots \ldots . .30$

$2 \cdot 50$

$.35 \quad 3.00$

25.00

20.00

17.00

3000

Plicatum (Japan Snow Ball) 2 to $3 \mathrm{ft} . \ldots . \ldots .50 .50$

250

2.00

3.00

$25 . \mathrm{CO}$

66

$$
21 / 2 \text { to } 3 \mathrm{ft}
$$

.35

.30

$2 \cdot 50$

Lantana 2 to $3 \mathrm{ft} \ldots \ldots \ldots \ldots \ldots \ldots \ldots \ldots \ldots . . . \ldots \ldots$

2.50

Xanthoceras Sorbifolia (Chinese Chestnut) 2 to $2 \frac{1}{2} \mathrm{ft}$. 1.00

\section{CLIMBING VINES.}

Ampelopsis Veitcheii 3 year strong.

Each. Per io. Per 100.

$$
\text { "6 }
$$

26

"6

$\$ 0.30 \quad \$ 2.50$

$\$ 20.00$

66

Quinquefolia 3 year strong

66

Engel

Akebia Quinata

elmanni 3 year strong.

.25

2.00

17.03

$.25 \quad 2.00$

17.00

.30

2.50

20.00

Bristolochi

.25

.50

4.00

.25

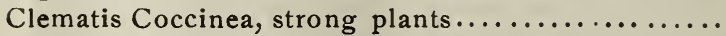

.40

3.00

.60

5.00

4.5 .00

Jackmanii and Henryii, strong plants........

.30

2.50

20.00

"G Gypsy Queen, strong plants............ .60 5.00 
liach. Per io. Per roo.

Clematis Miss Batemann, strong plants..........\$0.60 \$5.00

"Standishii, strong plants.............. . $5 . .60$

"Mad. Koster, strong plants .............. . . 5.00

" Duchess of Edinburgh, strong plants....... .60 5.00

Celastrus Scandens (Bitter Sweet) ............. .25

Hedera Hibernica (Irish Ivy) strong plants ............ $20 \quad 2.50$

Honeysuckle, Climbing, strong plants, assorted varie-

ties Aurea, Reticulata, Halleana,Scarlet Trumpet,

Chinese Evergreen, Monthly Fragrant, Brachy-

poda, Flava, Floribunda Alba, Fuchoides, Flava

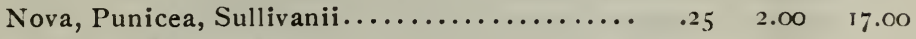

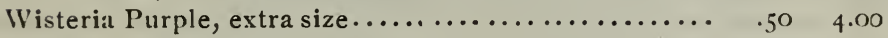

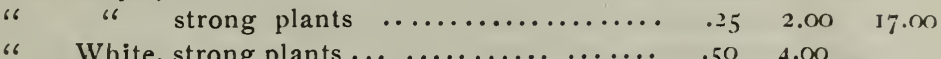

"White, strong plants ............... $\quad .50 \quad 4.00$

\section{HEDGE PLANTS.}

Osage Orange I year No.

Per roo Per I 000

California Privet, Pyrus Japonica, Althea, Berberry, Philadelphus, Roses, Spireas, Tart. Honeysuckle, Arborvitae, Ilemlock Spruce, etc., suitable for hedging will be found priced under proper headings in this Price I,ist. Smaller sizes than quoted in this list will be priced on application.

\section{ROSES.}

30,000 Field Grown to offer Fall 1907 and Spring 1908.

Our Roses are all field grown plants, on own roots, (we do not grow or handle budded Roses) and for Fall delivery will be fresh dug; for Spring delivery we winter our Roses in "Cold Frames" and can deliver in spring as early as weather will permit.

We advise Fall planting as being the best.

Note our fine list of varieties. We call especial attention to our large list of "Everblooming Roses" or Hybrid Teas."

Place your orders early, for best selection.

Hybrid Perpetuals, strong plants in dormant condition,

Each Per 1o. Per Ioo.

late fall or early spring delivery ............. \$0.30 \$2.50 \$20.00

Alfred Colombe,

Anna de Diesbach.

Boule de Neige (Hy. Noisette.)

Baron de Bonstettin.

Captain Hayward.

Clio.

Coquette de Alps(Hyb.Noisette.) Marchioness of Lorne.

"6

La Reine.

Mademoiselle Marie Rady.

Mad. Chas. Wood.

Mad. Masson.

Mad. Plantier (June Rose.)

Margaret Dickson.

Mrs. John Laing. 
Duke of Edinburgh.

Earl of Dufferin.

Francois Levet.

Gloire de Exposition Bruxelles

Gen'l. Jacquiminot.

Gloire Lyonaise.

Jubilee.

Lady Helen Stewart.
Paul Neyron.

President Lincoln.

Prince Camille de Rohan.

Roger Lambelin.

Robert Duncan.

Ulrich Bruner.

Vicks Caprice.

Everblooming Roses (Hybrid Teas, Teas, Polyantha,

Bourbon and China) strong plants, on own roots,

dormant cundition, late fall or early spring deliv-

ery. We advise fall planting ................ \$0.30 \$2.50 \$20.00

Everblooming Roses (Hybrid Teas, Etc.) from 4 to 5 in.

pots, April and May I9oS delivery only .......... .40 $3.50 \quad 30.00$

Antoine Rivoire (H. T.)

Bridesmaid (Tea.)

Champion of the World (B.)

Mad. Schwaller (H.T.)

Clothilde Soupert (H. Poly.)

Mad. Franciska Kruger (Tea.)

Meteor (H. T.)

Cardinal (H. T.)

Duchesse of Albany (H. T.)

Duchess de Brabant (Tea.)

Etoile de Lyon (Tea.)

Etoile de France (H. 'T. )

Gruss an Teplitz (H. T.)

Helen Gould (H. T.)

Hermosa (B.)

Killarney (H. T.)

Marie Guillot (Tea.)

Marie Van Houtte (Tea.)

Maman Cochet (Tea.)

Mrs. B. R. Cant (Tea.)

Perle des Jardines (Tea.)

Pierre Guillot (H. T.)

Rosomane Graveraux (H. 'l'.)

Richmond (H. T.)

Sombreuil (B.)

Kaiserin Augusta Victoria (H. T.)

Lady Battersea (H. T.)

La France (H. T.)

La Detroit (H. T.)

Mad. Abel Chatenay (H. T.)

Mad. Jules Grolez (H. T.)

Mad. Caroline Testout (H. T.)

Souv, de la Malmaison (B.)

Souv, de Pres. Carnot (H. T.)

Triumph de Pernet Pere (H. T.)

The Bride (Tea.)

Viscountess Folkestone (H. T.)

White Maman Cochet (Tea.)

White La France (Augustine Guinnoisseau) (H. T.)

Each. Per io. Per 100.

Baby Rambler (Madame Norbert Levavasseur) New

dwarf ever-blooming Crimson Rambler, dormant...\$0.30 \$2.50 \$20.00

$\begin{array}{llll}\text { Baby Rambler in } 4 \text { and } 5 \text { in. pots April and May delivery } \quad .40 \quad 3.50 \quad 30.00 & 3.50\end{array}$

Climbing Roses (Everblooming)

Cl. Kaiserin Augusta Victoria.

Cl. Meteor.

Gainesborough.

$.30 \quad 2.50$

Mary Washington.

Climbing Roses (Hardy) .................... $\quad .30 \quad 2.50 \quad 20.00$

Baltimore Belle.

Prairie Queen.

Crimson Rambler. Philadelphia Rambler. 
Dorothy Perkins. White Rambler.

Empress of China. Yellow Rambler.

Trailing Roses............................. .30 $2.50 \quad 20.00$

Mandas Triumph. Wm. C. Egan. Wichuriana.

Moss Roses, Crimson and White................ $\quad .35 \quad 3.00$

Sweet Briars (English) ..................... $\quad .35$

$\begin{array}{llll}\text { Rosa Rugosa (fine for Hedging) Alba and Rubra...... } & .30 & 2.50 & 20.00\end{array}$

Tree Roses, good assortment. Imported plants, Spring

Igos delivery........................ 1.00

\section{SPECIAL ROSE OFFER.}

Roses from $2^{1 / 2}$ inch pots, May Ist, 1908 , shipment.

We annually contract for a large amount of Roses for our own planting, out of which we offer to those wishing a cheaper plant; varieties out of our Hybrid Perpetual and Everblooming list, at special prices.

Last Spring we sent out quite a number of these small Roses and they have given excellent satisfaction.

At the prices quoted no one need be without a nice bed of Hybrid Perpetual or Everblooming Roses the coming year. Try them.

Orders for this class of Ruses should reach us on or before April Ist, 1goS, so that varieties can be reserved. We cannot accept orders for this class after our own planting has been completed.

In assortment, either H. P. or Everblooming.

Per ro................................. Postage prepaid.

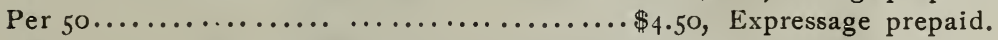

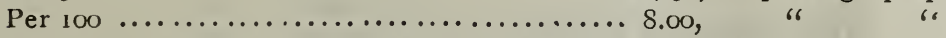
Packed in neat boxes. No order accepted for less than $\$ 1$.oo on this offer.

\section{GREENHOUSE ROSES.}

Under this class we offer only those suitable for

Each. Per 10. Per 100. forcing, 3 to 4 in. pots (Spring I908 delivery)........ \$0.20 \$1.50 \$12.00

Bride, Bridesmaid, Perle, Richmond and Killarney.

\section{EVERGREENS.}

All our Evergreens have been one or more times transplanted, they have fine fibrous roots and wherever possible we dig with ball of earth and wrap same in damp burlap; otherwise we pack roots in wet moss immediately after digging.

If you have not received our Descriptive Catalogue, or have misplaced same, send for another. 
CAUTION.-Do not let the sun or wind strike the roots of Evergreens even for a few minutes, you will kill them if you do. Plant immediately on receipt, give thorough drenching of water, but do not apply over the foliage.

Evergreens are best transplanted during September and April.

Those marked with $\left({ }^{*}\right)$ are Imported trees and can only be delivered during April 1908.

Each. Per io. Per roo.

$\Lambda$ bies Balsamea (Balsam Fir) 3 to $3 \frac{1}{2}$ feet with ball ...\$I.25 $\$ 10.00$

"6 66 "6 6 to 21 feet with ball.... 75 " 600

"Canadensis (Hemlock) 3 to $3 \frac{1}{2}$ feet with ball...2 2.00

"6 "6 62 to 3 feet with ball... I.5O

"66 66 2 to $2 \frac{1}{2}$ feet with ball.... 1.00

"6 * Concolor (Colorado Silver Fir) 3 to 4 feet with ball................... 5.00

" *Nordmaniana (Nordman's Silver Fir) 3 to 4 feet with ball.................... 3.50

Biota Orientalis (Chinese $\Lambda$ rbor Vitae) 4 to 5 feet

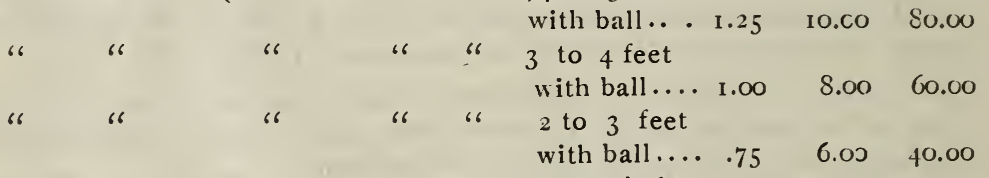

Juniperus Prostrala (Prostrate Juniper) 2 to $2 \frac{1}{2}$ feet with ball.... I.5O

" " " " IS to 24 in.

with ball.... 1.00

"Ilibernica (Irish Juniper) 4 to $.5 \mathrm{ft}$ with ball.. 1.50

" " " " " 3 to $4 \mathrm{ft}$ with ball.. 1.00

8.00

" "6 " 2 to $3 \mathrm{ft}$ with ball.. .75

" Virginiana (Red Cedar) 2 to 3 feet with ball.. $\quad .75$ Picea $A$ lba (White Spruce) $2 \frac{1}{2}$ to 3 feet with ball.... I.OO

" " " " " 2 to $2 \frac{1}{2}$ feet with ball .... 75

" " " " 6 18 $24 \mathrm{in.} \mathrm{with} \mathrm{ball....} \mathrm{.} \mathrm{.50}$

"*Alcoquiana (Alcock's Spruce) 3 feet with ball... 3.50

" " " " 2 feet with ball.... 2.00

"Engelmanni (Engelmann's Blue Spruce) 3 feet

"6 " " " 62 feet

with ball... 3.00

with ball...2 2.00

"Excelsa (Norway Spruce) + to 5 feet with ball... 2.50

" " " " " 3 to 4 feet with ball.... 1.50

" " " " $62 \frac{1}{2}$ to 3 feet with ball... 1.00

$12.50 \quad 100.00$

5.006000 
Fach. Per io. Per ioo.

Picea Excelsa (Norway Spruce 2 to $2 \frac{1}{2}$ feet with tall ... \$0.75 \$6.00 \$50.0n

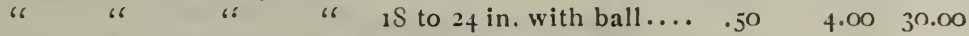
"Pungens (Colorado Spruce) Green form

$2 \frac{1}{2}$ to 3 feet with ball 1.25

"6 " " 6 2 to $2 \frac{1}{2}$ feet with ball. 1.00

6 *Pungens Glauca Koster (Koster's Blue Spruce)

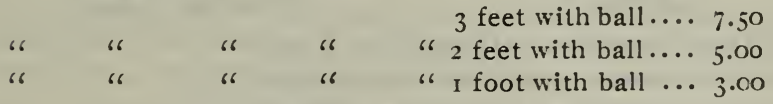

Pinus Austriaca (Austrian Pine) 3 to 4 feet......... I.oo

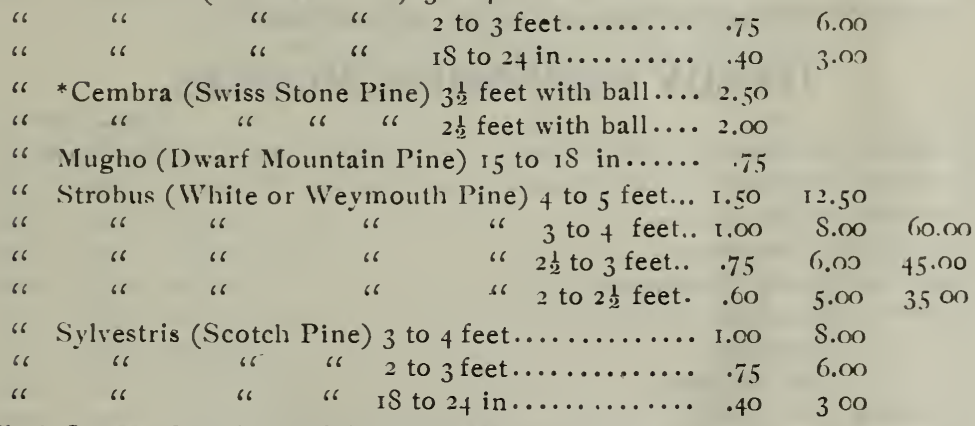

Thuja Lutea (Geo. Peabody) 2 to 3 feet with ball... 2.00

" Occidentalis (American Arborvitae) 5 to 6 feet

with ball... 2.50 20.00

$66 \quad 66 \quad 4$ to 5 feet

with ball...2 2.00 15.00

66 66 66 3 to 4 feet

with ball... I.00 $\quad 7.50 \quad 60.00$

$66 \quad 66 \quad 66 \quad 2 \frac{1}{2}$ to 3 feet

with ball .... $75 \quad 600 \quad 40.00$

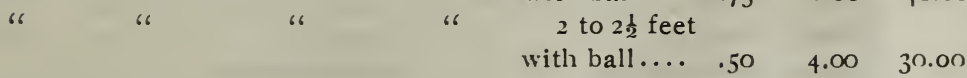

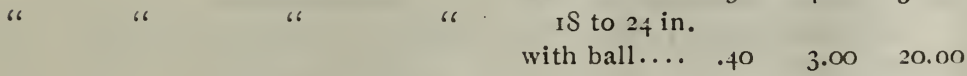

6 6 Pyramidalis (Pyramidal Arborvitae)

4 to 5 feet with ball....2.00

"6 $66 \quad 3$ to 4 feet with ball.... I.50

66 "6 2 to 3 feet with ball... $\quad .75$

" "Globosa (Globe Arborvitae) 15 to $1 S$ in.

with ball.... $\quad 75$ 


\section{EVERGREEN SHRUBS.}

Spring igoS Delivery.

Kalmia Latifolia (Mt. Laurel) 2 to $2^{1 / 2}$ feet with ball .. $\$ 2.00$ " " " 6 I to 2 feet with ball.... I.30

Mahonia Aquifolia is to $2+$ in ..................... 50 \$t.no " " 15 to $\mathrm{x} S$ in .................... . 40

Rhododendrons, Hardy American (Catawbiense Type)

Named varieties, Imported, 24 to 30 in. 15 to 25 buds. 2.50 Rhododendrons, Hardy American (Catawbiense Type)

Named varieties, Imported, IS to 24 in. 15 to 20 buds. 1.75

\section{HARDY PERENNIAL PLANTS.}

Achillea Ptarmica fl. p'. (The Pearl) ................. \$0.15 \$1.25

Aconitum Napellus.............................. .15 1.25

Adonis Vernalis.... .............................. $\quad .25 \quad 2.00$

Agrostemna Coronoria ........................... . . $15 \quad 1.25$

Alyssum Saxatile Compactum fl. pl................... $\quad .25 \quad 2.00$

Anemone Pensylvanica............................ .20 1.50

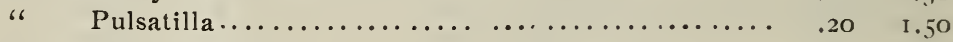

"6 Eliza Fellman......................... .25 2.c0

Anthemis Tinctoria...............................$_{15} \quad 1.25$

Aquileg:a Chrysantha, Coerulea, Nivea Grandiflora........ $\quad$.I 5 . 1.25

Arenaria Montana................................ .15 1.25

Armeria Maritima Splendens....................... ${ }_{115} \quad 1.25$

" " Alba............................. $15 \quad$ I.25

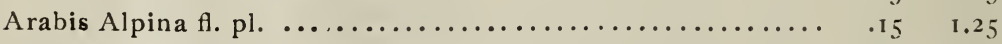

Artemesia Abrotamnum..............................$_{15} \quad$ 1.25

" Stellariana............................ $15 \quad 15$

Asclepias Tuberosa............................... .15 1.25

Asters (Hardy Alpine), Alpinus Superbus ...............$_{15} \quad 1.25$

" Alpinus Albus.............................. $\quad$.15 1.25

Asters (Hardy) Amethystinus, Mrs. F. W. Raynor, Novae

Angliae, Robert Parker, White Queen................ .15 $\quad$ I.25

Bambusa Aurea............................ ז.0

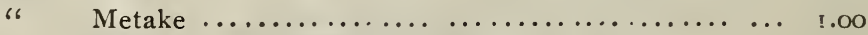

" Simoni............................ 1.00

Baptisia Australis............................. .15 1.25

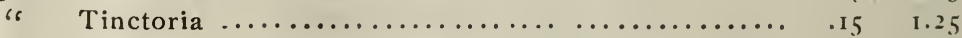

Bocconia Cordata................................ $15 \quad 1.25$

Boltonia Asteroides............................. $\quad .15 \quad 1.25$

" Latis 
Fach. Per 10.

Campanula Carpatica

\$0.15 \$1.25

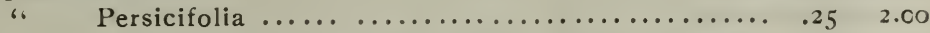

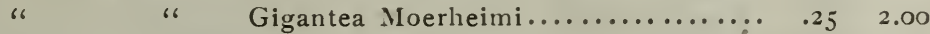

" Pyramidalis......................... .20

1.75

6

Grosseki............................ . 5

1.25

Callirhoe Involucrata $\ldots \ldots \ldots \ldots \ldots \ldots \ldots \ldots \ldots \ldots \ldots \ldots \ldots \ldots \ldots \ldots$

1.25

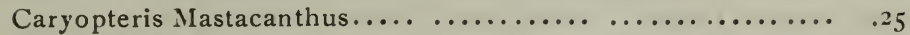

2.00

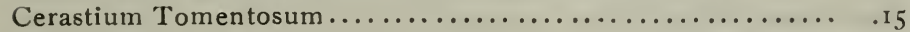

I.25

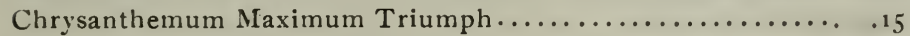

1.25

66

Shasta Daisy

. I 5

I. 25

" (Hardy Pompone) Baby, Eagle d'Or, Globe d' Or, Julia Lagravere, Princess of Wales, Rhoda,

Sour Melaine, Strathmeath..............

Clematis Recta

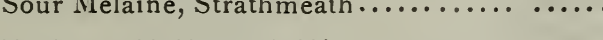

Coreopsis Lanceolata Grandiflora.... ... ... .........

Delphinium Chinensis, Belladonna, Formosum, Sulphureum..

Dianthus Barbatus...

Dictamnus Fraxinella Alba

Dielytra Spectabilis

Digitalis Gloxiniaeflora

Doronicum Excelsum.

Eupatorium Ageratoides

Euphorbia Corollata

Funkia Coerulea.

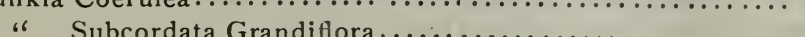

Undulata Media picta.

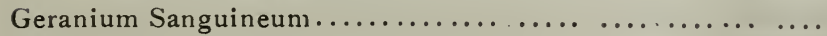

Gaillardia Grandiflora..

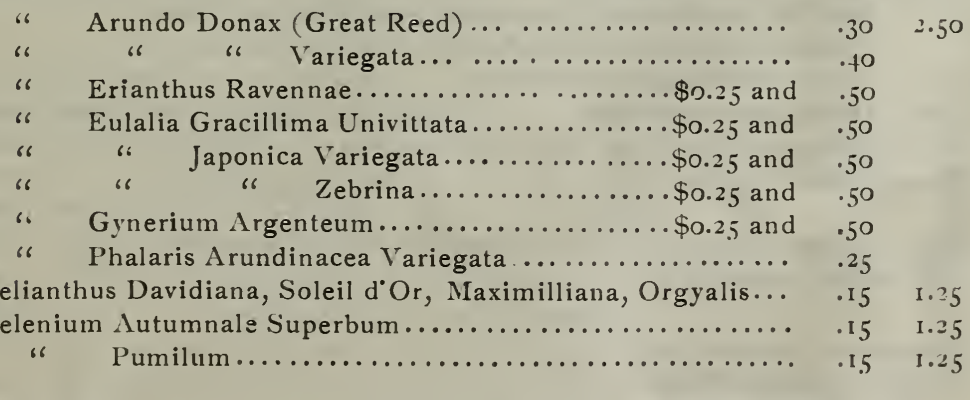


Heliopsis Pitcherianus.

Fach. Per 10.

Hemerocallis Flava.... $\$ 0.15 \$ 1.25$

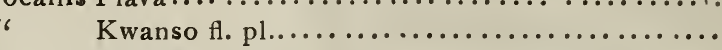

$.15 \quad 1.25$

$.15 \quad 1.25$

Heuchera Sanguinea............................. . I5 1.25

Hibiscus Moschuetos............................... .15 1.25

6 66 Crimson Eye

. I 1.25

Hollyhocks (Superb Double) White, Pink, Salmon, Yellow,

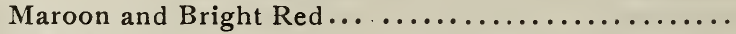

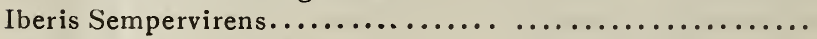

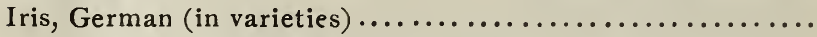

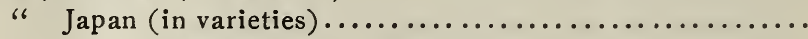

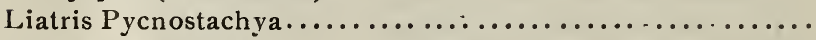

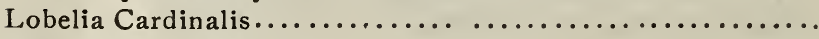

Lychnis Chalcedonica.
66
is
66
fl. pl.
Alba
Viscaria

2.00

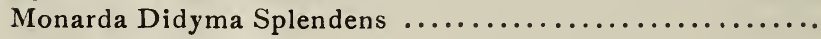

Oenothera Speciosa.

Chrysanthemiflora, Festiva Alba, Louis Van Houtte,

Rubens, Alba Plena, Bicolor, Mme. Furtado, Duchesse de Orleans, Gen. Cavaignac, Mme. Chaumay, Tricolor Grandiflora, Agida, Daniel Tortman.

l'apaver Orientale............................... .20

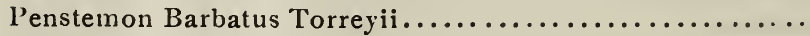

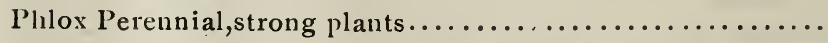

$\Lambda$ quillon, Bridesmaid, Beranger, Champs Elysce, Coquelicot, Eclaireur, Eugene Danzenvillier, Jean d' Arc, Prof. Schliemann, Pantheon.

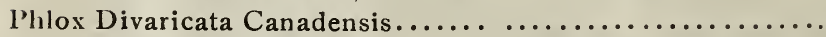

" Subulata, The Bride, Rosea and Lilacina............

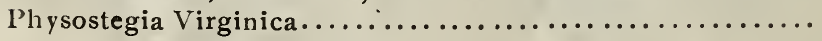
"6

$\Lambda \mathrm{lba}$

Pinks (Hardy Garden), Comet, Delicata and White Reserve.. l'latycodon Grandiflorum.

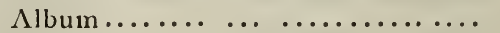

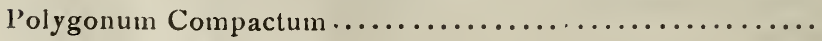

P'rimula Cortusoides Seiboldii . 
Pyrethrum Hybridum fi. pl., Alfred Kelway, Carl Vogt, Each. Per ro.

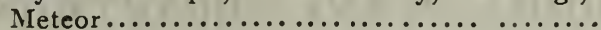
$\$ 0.30 \quad \$ 2.50$

" Uliginosum.

$.15 \quad 1.25$

Ranunculus Acris t. pl.

. $15 \quad 1.25$

Rosemarinus Officinalis

Salvia Azurea Grandiflora.......................... . I $_{5}$

1.25

Rudbeckia Laciniata (Golden Glow) $\ldots \ldots \ldots \ldots \ldots \ldots \ldots \ldots \ldots$.I5

1.25

1.00

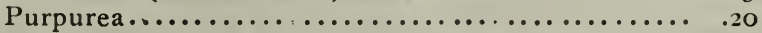

I. 50

Scabiosa Caucasica.............................. .20

I. 50

Sedum Acre...................................... .15

I.25

Senecio Pulcher...

.25

Spirea Phillipendula fl. pl.

2.00

I. 50

" Palmata................................... .20

Stokesia Cyanea................................. .20

Thalictrum Aquilegifolium Album.................... .20

1.50

1.50

1.50

Roseum................... .20

1.50

Trycyrtis Hirta...

1.25

Trillium Granditlorum ............................. .15

Tritoma Uvaria................................. .20

1.25

" Pfitzerii . .

1.50

Trollius Europaeus

.20

1.50

Veronica Incana ..

Rosea...................................... .

1.25

Spicata Alba............................. .15

Yucca Filamentosa.

Extra....

1.25

4.00

"6

66

mediurn

.50

2.50

\section{BULBS AND TUBERS.}

\section{For Spring planting and delivery only, except Liliums.}

Cannas (Dormant roots) assorted varieties

Fach. Per Io.

" - (growing plants in pots) after $\mathrm{Ma}$ \$0.15 \$1.00

Convallaria (Lily-

Caladium Esculentum, Extra size bulbs...

First

Calla Lillies

Dahlia-Double-in assortment

Lilium Auratum, select bulbs....................... ${ }_{25}$

"، "

Candidum

Speciosu

"6

“

Albuin. .

Rubrum

ene.

.10

.25

2.00

2.00

I. 25

Tigrinum H. pl 


\section{GREENHOUSE PLANT DEPARTMENT.}

Abutilon (Flowering Maple)-Popular pot plants or for bedding, vases and baskets. Each 15 cts., per doz. \$1.50.

Acalypha Sanderi (Chenille Plant) - Showy foliage plants for ornamental and sub-tropical bedding. Each ro cts., per doz. \$1.00.

Achyranthes-Graceful foliage plants, fine for bedding. Each Io cts. per doz. \$1.00.

Ageratum Stella Gurney-Low growing, bushy border plant or for bedding, fine blue flowers. Each ro cts., per doz. \$1.00.

Alternanthera-Fine foliage plants for bordering flower beds or carpet bedding. Yellow, Red and Bronze. Each 5 cts., per doz. $50 \mathrm{cts}$., per $100 \$ 4.00$.

Asparagus Plumosus Nanus-Fine for single pot plants and indispensable for floral decorations. Each 25 and $50 \mathrm{cts}$.

Asparagus Sprengeri-Graceful pot plant for house decoration, or for hanging baskets. Each 25, 50 and $75 \mathrm{cts}$.

Begonias, Flowering Varieties-Popular house plants. Argentea Guttata, Flambeau, Drewdrop, Metallica, Otto Hacker, Rubra, Warscewice. Each $25 \mathrm{cts}$. Specimen plants, prices on application.

Begonia Rex Varieties-Fine pot plants for house decoration, baskets and vases. Each 25 to $50 \mathrm{cts}$.

Coleus, Assorted Varieties-Fine for carpet bedding and borders for Canna beds. Each 5 cts., per doz. $50 \mathrm{cts}$., per $100 \$ 4.00$.

Cyperus Alternifolius-A splendid aquatic plant. Each ro to $25 \mathrm{cts}$.

Dracena-Noted for the odd and beautiful foliage. Each $50 \mathrm{cts}$. to $\$ 1.50$.

Ferns, Nephrolepis Scotti-4 inch pots. Each $75 \mathrm{cts}$., 5 inch pots, each $\$$ s.00.

Ferns, Nephrolepis Bostoniensis-4 inch pots, Each $50 \mathrm{cts}$, 5 inch pots, Each 75 cts. Specimen plants, each $\$ 1.00$ to $\$ 1.50$.

Ferns. Nephrolepis Elegantissima -5 inch pots. Each $\$ 1.00$.

Fuchia-Splendid window plant, or for shady spots in the garden. Each I 5 and 20 cts., according to size.

Ficus Elastica-Best house or table decoration plant. Each 50, $75 \mathrm{cts}$. and $\$ 1 . c 0$, according to size.

Geraniums-The most popular flower for summer bedding. Our collection comprises many fine varieties, both single and double in the various shades. Extra plants, each I $_{5} \mathrm{cts}$, per doz. \$1.50, per 100 $\$ 10.00$. No. I plants, each ro cts., per doz. $\$ 1.00$, per $100 \$ \$ .00$. 
Geraniums, Ivg-leaved-Fine for baskets or vases or where a trailing or climbing plant may be desired. Strong plants. Each 15 cts., per doz. \$1.50.

Geraniums, Scented-leaved-Strong plants. Each $15 \mathrm{cts}$.

Heliatropo-A favorite flower with everyone, strong plants. Each $15 \mathrm{cts}$, per doz. \$1.50.

Hibiscus Sinensis-Single red and pink, double red and pink. Each 25, $50 \mathrm{cts}$. and $\$ \mathrm{r} .00$, according to size.

Lantana-Showy bedding or basket plants. Each I $_{5} \mathrm{cts}$., per doz. \$1.50. Moonflower (Mexican.)-The fastest growing climbing annual. Each $20 \mathrm{cts}$., 2 for $35 \mathrm{cts}$.

Palms, Areca Lutescens- 5 inch pots, 24 inches high, Each $\$ 1.00$.

“ Kentia Belmoriana-5 inch pots, 24 inches high, Each $\$ 1.50$.

“ Kentia Fosteriana-5 inch pots, 20 inches high, Each \$1.50.

6. Latania Borbonica-5 inch pots, iS inches high, Each \$1.00.

Pandanus Veitchii -5 inch pots, 15 inches high, Each $\$$ I. 00 . 6 inch pots IS inches high, Each \$1.50.

Salvia (Scarlet Sage)-One of the most popular bedding plants. Select plants, each $15 \mathrm{cts}$., per doz. $\$ 1.50$, per $100 \$ 10.00$. No. I plants, each to cts., per doz. $\$ 1.00$, per roo $\$ 8.00$.

Tradescantia (Wandering Jew)-Splendid plants for baskets and window boxes, Each 5 and ro cts., according to size of plants.

Vinca Major Variegata-A popular plant forvases, baskets and window boxes. trailing vine. Each 15 to $20 \mathrm{cts}$., according to size of plants.

Vinca (Perrywinkle)-One of the best plants for bedding and for borders, in bloom all summer, we have it in 3 varieties, white, white with red eye and red, Each 5 cts., per doz. 50 cts., per $100 \$ 4.00$.

\section{VEGETABLE PLANTS.}

Ready at proper time for planting in Spring.

Cabbage-Early Jersey Wakefield and Brunswick, per Io0 $25 \mathrm{cts}$, per 1000 $\$ 2.00$.

Cauliflower-Dwarf Erfurt. Per Ioo $\$$ r.oo.

Kohlrabi-Per 10020 cts.

Beets-Per 10020 cts.

Lettuce-Per $10020 \mathrm{cts}$.

Tomato-Seed bed, per $10030 \mathrm{cts}$. Transplanted plants, per $100 \$ 1.00$.

Sweet Potatoes-Early Bermuda, Late Red and Late Yellow, per Ioo 25 cts.,per $1000 \$ 2.00$. 


\section{PRATT'S}

\section{"SCALECIDE"}

Manufactured Only By

\section{B. G. PRATT CO., NEW YORK.}

\section{is an absolutely unfailing Remedy for "SAN JOSE SCALE."}

Attested to by thousands who have used it. If you have not tried it SPRAY NOW as soon as leaves begin to fall. DON'T WAIT until the Scale has sapped the life out of your trees. Cheaper and more effective than Lime, Sulphur and Salt or any other home-made or commercial spray. A 5 per cent solution guaranteed to kill every scale touched with it. One enthusiastic customer remarked that it killed 100 per cent of all scale it hit, and $g$ per cent that it did not hit.

\section{PRICES OF "SCALECIDE,"}

F. O. B. HACKENSACK, N. J., or NEW YORK, N. Y.

50 Gallon Barrels, 50 cents per gallon..............\$25.00 30 " one half Barrel, $\$ 1.00$ extra................ 16.00 10 "Jacketed Cans........................ 6.00

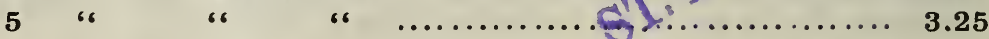

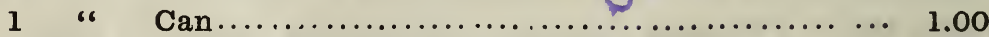

(I gallon makes 16 to 20 gallons of spray.)

TERMS:-Cash with order. St. Louis Exchange, Post Office or Express money-order.

\section{Directions for Using Pratt's "Scalecide."}

Fill spray tank first with water, and add I gallon of "Scalecide" for every 20 gallons of water; agitate slightly and it is ready for use.

Twice the quantity of "Scalecide" may be used if desired. It will not injure the tree. Commence spraying in the Fall, just after the leaves fall. Spray any time during the Winter or Spring, that it is comfortable to work out doors, up to the time that the blossoms are beginning to open. When spraying is done for Cottony Maple Scale, will be pleased to give special directions.

"Scalecide" is antiseptic and healing to the skin. Absclutely non= poisonous.

\section{SEND ORDERS TO}

\section{H. J. Weber \& Sons Nursery Co.,}




$$
\begin{aligned}
& \text { SEe Page } 32 . \\
& \text { For Prices on } \\
& \text { SCALEOIDE" }
\end{aligned}
$$

